\title{
Resimli Öykü Kitaplarının Temel Matematik Becerileri Açısından İncelenmesi *
}

\section{Study of Basic Mathematical Skills of Picture Story Books}

\begin{abstract}
Demet ARSLAN BAŞDAĞ**, H. Elif DAĞLIOĞLU****
Öz: Bu çalışma, 3-6 yaş grubu çocuklarına yönelik olarak yerli ve yabancı yazarlar tarafından yazılmış olan resimli öykü kitaplarının resim ve metin kısımlarında, temel matematik becerilerine ne oranda yer verildiğini tespit etmek amacıyla yapılmıştır. İncelenen kitaplar, 2005-2017 yılları arasında yayımlanmış, 3-6 yaş çocuklarına yönelik, kitapların metin ve/veya resim kısmında temel matematik becerilerine yer verilen toplam 147 kitaptan oluşmuştur. Elde edilen veriler, betimsel analiz yöntemi kullanılarak çözümlenmiştir. Matematik becerileri açısından bakıldığında öykü kitaplarının metin kısımlarının $\% 18,88$ 'inde, resim kısımlarının ise \%34,22'sinde bu becerilere yer verildiği bulunmuştur. Resimli öykü kitaplarının metin kısımlarında geçen temel becerilerinin dağılımlarına bakıldığında en çok sayma, karşılaştırma ve sıralama becerilerine rastlanırken en az birebir eşleme ve gruplama becerilerine yer verildiği belirlenmiştir. Resimli öykü kitaplarının resim kısımlarında geçen temel matematik becerilerinin dağılımlarına bakıldığında ise en fazla sayma, karşılaştırma ve sıralama becerilerine rastlanırken en az birebir eşleme ve gruplama becerilerine yer verildiği belirlenmiştir. İncelenen dokuz kitapta çocukların gelişimsel özelliklerine uygun olmayan şiddet içerikli metin ve resimlere rastlanmıştır. Bu sonuç, çocukların yüksek yararı düşünüldüğünde onların gelişimini olumsuz etkileyecek herhangi bir durumla karşılaşmamaları konusunda oldukça hassas davranılması ve bu bağlamada sorumluluğu olan bütün paydaşların bilinçli olması gerektiğini ortaya koymaktadır
\end{abstract}

Anahtar Kelimeler: Okul öncesi dönem, resimli öykü kitapları, matematik becerileri

\begin{abstract}
This study was conducted in order to determine how the pictures and text parts of the picture story books written by the local and foreign writers for the 3-6 age group children were included in the basic mathematical skills. The study group consisted of 147 books which were published between 2005 and 2017, and for the children aged 3-6, in the text and /or picture section of books, the basic mathematical skills were included. In terms of mathematical skills, it was found that $18.88 \%$ of the text parts of the story books and $34.22 \%$ of the picture parts included these skills. When it was looked at the distributions of basic mathematical skills in the text parts of the picture story books, it was determined that the most counting, comparison and sorting skills were found, and at least one-to-one correspondence and grouping skills were included. When it is looked at the distributions of the basic mathematical skills in the picture parts of picture story books, the most counting, comparison and sorting skills are found, and at least oneto-one correspondence and grouping skills are found. In general, it has been determined that the number concepts and at least one-to-one correspondence skills are included in the text and picture section of the books. When the books were examined in terms of their suitability for the development of children, it was found that nine books had basic skills. In the nine books that were examined it was come across violent text and images which were not suitable for the developmental characteristics of children. This result suggests that when the best interests of the children are considered, they should be treated very sensitively in order not to encounter any situation that will adversely affect their development and that all stakeholders should be conscious in this context.
\end{abstract}

Keywords: Preschool period, Picture story books, mathematic skills

\footnotetext{
* Bu makale ilk yazarın yüksek lisans tezinden üretilmiştir.

** Doktora Öğrencisi, Gazi Eğitim Fakültesi, Ankara-TÜRKIYE ORCID:0000-0003-4560-3043, e-posta: basdagdemet7@gmail.com

*** Prof. Dr., Gazi Üniversitesi, Gazi Eğitim Fakültesi, Ankara-TÜRKIYY, ORCID: 0000-0002-7420-815X, e-posta: edaglioglu1@gmail.com
} 


\section{Giriş}

Matematik; aritmetik, geometri, cebir, uzunluk, kütle, hacim, grafik, sayılar gibi matematiği oluşturan kavramlar ve bunların birbiriyle ilişkilerini ve sembollerini kapsayan bir bilim dalıdır (Güven, 2005). Bu bağlamda matematik becerileri denildiğinde ise; matematiği sembolleri ile düşünebilme, matematiksel işlemlerde esneklik, tersine çevirebilirlik ve matematikle ilgili konularda belleği kullanma gibi özellikleri gösterebilmek olarak ifade edilmektedir (Güven ve Uyanık-Balat, 2006).

Günümüzde matematik eğitim ve öğretiminde; materyal, akran, aile, öğretmen ve çevre ile etkileşim halinde, ezberleyerek değil anlayarak öğrenildiği bir görüş hakimdir (Charlesworth, 2005). Amerika'daki Ulusal Matematik Öğretmenleri Konseyi (National Council of Teachers of Mathematics [NCTM], 2006), matematik eğitiminde uluslararası düzeyde kabul gören bir kuruldur ve çalışmaları matematik alanında referans kabul edilmektedir. NCTM'nin belirlediği standartlar çerçevesinde matematik etkinlikleri sırasında çocuklara kazandırılması gereken erken matematik içeriği birebir eşleme, sınıflama, karşılaştırma, sıralama, örüntü, ölçme, geometri ve sayma olarak sıralanabilir (Milli Eğitim Bakanlığı [MEB], 2013; NCTM, 2006).

Çocuklar, içgüdüsel olarak dünyayı tanıma ve keşfetme duygusu ile doğarlar. Özellikle çocuklar ilk üç yaş içerisinde matematik kavram ve becerilerini öğrenirlerken beş duyularını kullanırlar. Bebekler ilk aylardan itibaren "boyut, ağırlık, şekil, zaman ve uzay" kavramlarını öğrenmeye başlarlar (Aktaş- Arnas, 2013; Charleswoth ve Lind, 2003). Bebek ve küçük çocuklar ilk üç yıl boyunca oluşturdukları yetenekleri erken çocukluk yılları boyunca (bazı alanlarda yaşam boyunca) gelişmeye devam eder. NCTM'ye göre çocuklar, ilk üç yaş içerisinde öğrenmeye başladıkları kavramlarla ilgili bilgi, beceri ve deneyimlerini arttırılar. 3-5 yaşları arasında nesnelerin temel özelliklerine (renk, şekil ve boyut gibi) ve ilişkili kavramları sınıflama konusunda becerileri gelişir. Günlük yaşam içerisinde karşısına çıkan problemleri neden-sonuç ilişkisi kurarak, nesneleri özelliklerine göre ayrıştırarak akıl yürütme konusunda deneyim kazanmaya başlarlar. Özellikle bütün bu becerileri kazanırken ağır-hafif, büyük-küçük, hızlı-yavaş ve uzunkısa gibi zıt kavramlar öğrenmelerini son derece kolaylaştırır (NCTM, 2006).

Gelman ve Gallistel'e (1978) göre; sayma becerisinin kazanımının beş temel ilkeye dayandığ1 görülmektedir. Bu ilkeler; değişmez sıra, birebir eşleme, kardinal değer, soyutlama ilkesi ve sıra-bağımsızlık ilkeleridir. Bu ilkeler saymanın nasıl yapılacağı ile ilgili işlemsel bilgi ve kuralları ifade etmekte ve çocuklarda sayma bilgisinin gelişimini önemli ölçüde şekillendirmektedir (Angın, 2013; Charlesworth ve Lind, 2013; Durmuşoğlu, 2013; Güven, 2002; Kandır ve Orçan, 2010). Bu ilkelerden de anlaşılacağı üzere sayı kavramının temeli birebir eşleme, sınıflama/gruplama, karşılaştırma ve sıralama gibi matematik becerilerine dayanmaktadır. Görüldüğü üzere sayma becerisinin birçok matematik kavramının kazanılmasında temel beceri olduğu görülmektedir. Sayma ve sayıları anlamak birçok karmaşık bilişsel sürecin bir arada kullanılmasını gerektirmektedir. Sayı kavramı, düşünme yeteneğini, basit şekilde sayılarla çalışmayı, sayıları sık sık kullanmayı, ilişkilerini anlamayı içerir (Dibek, 2017). Araştırmada birebir eşleme, gruplama/sınıflama, karşılaştırma, sıralama ve sayma; sayı kavramının alt yapısını oluşturan beceriler olması açısından bu araştırmaya dahil edilmekle birlikte belirtilen matematik becerileri sadece sayı kavramı bağlamında ele alınmayıp her biri ayrı ayrı kendi içeriği doğrultusunda da ayrıntılı olarak incelenmiştir.

Temel matematik becerileri dikkate alındığında okul öncesi eğitim sürecinde bunlarla ilgili aktivitelerin çocukların zihinsel gelişimine ve yeni kavramların öğrenilmesine uygun olacak şekilde planlanması gerekmektedir (Kandır ve Orçan, 2010). Matematik eğitimi rutin etkinlikler, müzik, masa, oyun, okuma yazmaya hazırlık, anadili etkinlikleri ile verilebilmektedir (Erdoğan ve Baran, 2003). Eğitim sürecinde öğretmenler matematik kavramlarının bulunduğu kitapları, rehber olarak kullanmaktadırlar. Özellikle anadili etkinlikleriyle çocuğun birçok matematiğe ilişkin temel becerileri öğrenmesine olanak sağlanmaktadır. Çocuk edebiyatının türleri olan şiirler, fikralar, bilmeceler, tekerlemeler, parmak oyunları ve öyküler gibi dil etkinlikleri içerisinde birçok matematik becerisi bulunmaktadır (Güven, 2002). Anadili etkinliklerinde kullanılan öykü, tekerleme ve parmak oyunlarında geçen matematiğe ilişkin unsurların, resimli öykü kitaplarında detaylı bir şekilde ele alınması matematik becerilerinin gelişmesine katkı 
sağlamaktadır. Türkçe etkinliklerinde matematik hakkında konuşmak, matematiğe özgü kelime ve kavramları kullanmak ve resimlerdeki matematik ile ilgili semboller üzerine çocuğun odaklanmasını sağlamak matematik eğitimi için son derece önemlidir (Fırat ve Dinçer, 2018).

Hong'a (1996) göre resimli öykü kitaplarının temel amacı matematiği öğretmek değildir ancak kitapların içerisinde geçen matematik unsurlarının farkına varılmasıyla matematik ile ilgili düşünmenin temelleri atılır. Kitaplar okunurken çocukların zihninde matematiğe ilişkin yeni resimler ve hareketler belirir. Çocuklar, bu yeni öğrenmeleri önceki tecrübeleriyle birleştirerek matematik üzerine olumlu algılar oluşturulabilir (Lowitt Clark, 1992). Nitekim 1996 yılında Hong'un yapmış olduğu çalışmada resimli öykü kitapları bir grup çocuğa okunarak matematikle ilgili bölümlere dikkat çekilerek çeşitli etkinlikler yapılmış ve sonuçta çocuklarda sınıflama becerisi ve sayı kavramında gelişmeler olduğu gözlenmiştir. Bununla birlikte Van den HevvelPanhuizen, Van den Boogard ve Doig'in (2009) araştırmasında öykü kitaplarının çocuklarda matematik ile ilgili düşünmeye yardımcı olduğu ortaya konmuştur. Aynı araştırmada amacı matematik öğretmek olmayan resimli öykü kitaplarının, çocukların matematiğe yönelik düşünmesine katkı sağlayacak çok fazla potansiyele sahip olduğu vurgulanmıştır. Thomas, Mulligan ve Golding'un 2002 yılında yapmış olduğu çalışmada ise görsel sunumların ve öykü kitaplarındaki resimlerin matematiksel düşünmeyi arttırdığ ve metinle görselin birbirini desteklediği kitapların çocuklara yararlı ve önemli katkılar sunduğu bulunmuştur. Böylelikle resimli öykü kitaplarının çocukların matematik eğitiminde eğlenceli bir atmosfer oluşturduğu ve matematik kavram ve becerilerini öğrenirken motive ettiği, matematikle ilgili olumlu algılar oluşturduğu söylenebilir. Bütün bu bilgiler doğrultusunda çocukların matematiği sosyal, kullanışlı ve değerli olarak görmeleri ve eğitim ortamına aktif olarak katılımları sağlanmış olacaktır (Schiro, 1997).

Okul öncesi dönemdeki çocuklara yönelik olarak hazırlanan resimli öykü kitaplarında, matematik becerilerine yönelik fursatları ele almadan önce belki de en çok dikkat edilmesi gereken kitaplarda çocukların gelişimini olumsuz yönde etkileyebilecek unsurların bulunup bulunmadığının incelenmesidir. Literatür incelendiğinde resimli öykü kitaplarının çocuğu sevgiyle sarmalayan, şefkatle öpen, güvenini perçinleyen, inanan, koruyan, yardıma koşan dostça duyguların yanı sıra tedirgin, korkulu, kaygılı olmanın aşılabilirliğini de duyumsatması gerektiğinin önemle üzerinde durulduğu görülmektedir (Tekin, 2005). Kitaplarda güncel yaşantı içerisinde kullanılan dilde sık karşılaşılmayan eski sözcüklerden ve özellikle de argo niteliğindeki kelimelerden kaçınılması gerekir (Oğuzkan, 1997). Şahin'e (2014) göre yaşam boyunca karşılaşılan resimlerin, öğrenme yaşantısında çok önemli bir yeri vardır. Resimler, çocukların kavramsal ve zihinsel gelişimlerini destekler. Estetik ve yalın bir resimleme ile metine gerek duyulmadan çocuklara aktarılmak isteneni aktarmak mümkündür (Özer, 2006). Güneş'e (2000) göre kitabın, çocukta olumlu duygulara olanak sağlaması için biçimsel özelliklerinin renkli, resimli ve çekici olması gerekmektedir. Okul öncesi dönemdeki çocuklar için kitap yazan/resimleyen kişilerin çocukların gelişimlerine ilişkin de bilgi sahibi olması beklenmektedir. Çocukların ruh sağlığını olumsuz yönde etkileyen korku, şiddet, kaygı, öfke, düşmanlık vb. duygular, bazen model alma yoluyla, bazen de kitaplar aracılığıyla öğrenilmektedir. Kitaplarda yer alan yaratıklar, hayaletler, avcılar, canavarlar, üvey anneler, cadılar gibi bir takım gerçek dışı varlıkların çocuklarda olumsuz öğrenmeler yol açtığı görülmektedir (Dağlıoğlu ve Çamlıbel Çakmak, 2010; Sever, 2003). Bu araştırmada temel amaç resimli öykü kitaplarında yer alan bazı temel matematik becerilerinin incelenmesi olmakla birlikte çocuğun yüksek yararı dikkate alındığında, kitapların sadece içerdiği kavram ve beceriler açısından değil, çocukların bütüncül gelişimlerine uygunluğu açısından da incelenmesinin önemi ortaya konmaya çalışılmıştır.

Resimli öykü kitaplarının eğitsel materyal olarak kullanıldığı bilinmekle birlikte bu konuyu inceleyen çok az sayıda çalışma olduğu görülmektedir (Gönen ve Veziroğlu, 2012; Powell ve Haag, 2015; Rogers, Cooper, Nesmith ve Cassidy, 2015; Yılmaz Genç, Akıncı Çoşgun ve Pala, 2017). Bu nedenle yapılan araştırmanın bulguları resimli öykü kitaplarında temel matematik kavramlarına ne düzeyde yer verildiğini göstererek ve çocukların gelişimlerine uyunluğunu ortaya koyarak bu doğrultuda daha bilinçli çalışmaların yapılabilmesi açısından yol gösterici olacaktır. Bu bağlamda araştırmada, aşağıdaki sorulara cevap aranmıştır. 
1.Okul öncesi dönemde kullanılan resimli öykü kitaplarının metin ve resim kısımlarında eşleştirme, gruplama, karşılaştırma, sıralama ve sayma becerilerine yer verilme düzeyi nedir?

2. Resimli öykü kitaplarında çocukların gelişimine uygun olmayan unsurlara yer verilme durumu nedir?

\section{Yöntem}

3-6 yaş arası çocuklar için yazılmış resimli öykü kitaplarında temel matematik becerilerine ne ölçüde yer verildiğini belirlemek ve bu kitapların gelişimlerine uygunluğunu ortaya koymak üzere yapılan bu çalışmada nitel araştırma yöntemleri kullanılmıştır. Ayrıca çalışmada tarama modelinin bir türü olan "betimsel tarama modeli" kullanılmıştır. Betimleme "Burada ne oluyor?" sorusuna cevap aramaktadır ve veri araştırmacı gözlem ya da raporlarından oluşmaktadır (Walcott, 1994).

\section{Veri toplama süreci ve analizi}

Araştırmanın kapsamında 2005-2017 yılları arasında 36-72 aylık çocuklara yönelik, yayımlanmış resimli öykü kitapları incelenmiştir. Öykü kitaplarının seçilmesinde en önemli kriter, içinde metin ve/veya resim kısmında temel matematik becerilerine yer verilmesidir. Araştırmada kitapların seçiminde kullanılan diğer kriterler ise; kitapların 2005-2017 yılları arasında yayınlanmış olması, hedef kitlesinin 3-6 yaş olması ve kitapların metin ve/veya resim kısmında temel matematik becerilerine yer verilmiş olmasıdır.

Verilerin toplanması sürecinde belirtilen kriterlerden yararlanırken bir sıra izlenmiştir. Öncelikle 2005-2017 arasında yayımlanan kitaplar ayrılmıştır. Daha sonra bu kitaplardan 36-72 aylık çocuklara yönelik kitaplar seçilerek içerikleri incelenmiştir. İçeriği incelenen kitaplardan metin ve/veya resim kısmında temel matematik becerilerine yer veren kitaplar araştırma kapsamında incelenecek kitapları oluşturmuştur. Araştırmada tüm bu kriterler ele alınarak toplam 147 tane resimli öykü kitabı satın alınarak incelenmiştir.

Kitapların metin ve resim kısımlarında matematik becerilerine ilişkin kodlamalar bu becerilerin aşağıda belirtilen özellikleri dikkate alınarak kodlanmıştır. Kitaplarda incelenen matematik becerilerinden eşleştirme bir kümedeki her bir nesneyi, diğer bir kümedeki her bir nesne eşlemeyi içerdiğinden, bir nesnenin bir veya daha fazla özelliğini tanımayı, tanımlamayı, nesnenin diğer nesnelerden farklarını ayırt etmeyi ve birebir ilişki kurmayı gerektirmektir (Charlesworth ve Lind, 2013; Lind, 2000). Sinıflama becerisi ise nesnelerin boyut, renk, şekil, yapısal özellikler gibi ortak özelliklerine göre biraraya gelmesidir. Sınıflama becerisi, nesnelerin benzer ve farklı özelliklerini fark etmeyi gerektirdiği için karşılaştırma (benzerlik-zıtlık) becerisinin gelişmesini ve ortaya çıkmasını sağlar (Aktaş-Arnas, 2002; Güven, 1997). AktaşArnas'a (2002) gore nesnelerin ölçülebilen veya ölçülmeyen özellikleri yönünden düzenlenmesi siralama olarak tanımlanabilir. Siralamada nesneler bir özelliklerine göre siraya dizilirler. $\mathrm{Bu}$ bağlamda sıralama karşılaştırmadan daha zor bir beceridir ve matematiksel sonuç çıkarma ve sayı sisteminin temelini oluşturur. Sayma becerisi ise; sayı kelimeleri ile somut fiziksel varlıkların koordinasyonu olup çocuklarda hiyerarşik bir düzen içinde gerçekleşir. Sayma becerisi; çocukların somut nesneler kullanarak birebir eşleştirme yapmalarını, sayı isimlerini sıralama bilgisini, el göz koordinasyonunu ve sözel becerileri gerektiren bilişsel bir aktivitedir (AktaşArnas, 2002; Güven, 1997). Bu bilgiler doğrultusunda resimli öykü kitapları sırasıly K1, K2, K3 ......K147 olarak kodlanmış ve ele alınan kitap öncelikle bir kez okunarak toplam cümle ve toplam resim sayısı belirlenerek kaydedilmiştir. Cümleler C1, C2, C3.., resimler R1, R2, R3... şeklinde kodlanmıştır. Kitaplar okunurken beceri içeren cümleleri yansıtan resimlerin olup olmadığına bakılarak bulunan resimler kitap inceleme formunun resim kısmına 'K3, R4', cümlelerde yer alan matematik becerileri ise ' $\mathrm{K} 3, \mathrm{C} 5$ ' şeklinde kaydedilmiştir. Aynı işlemler karşılaştırma, sıralama, gruplama, sayma becerileri içinde tekrarlanmıştır. Kitaplar matematik becerileri açısından incelenirken her bir kitap en az üç kez okunarak kodlanmıştır. Kitaplar her beceri türü için bağımsız olarak incelendiği için aynı cümle ve resim birden fazla beceriyi içerdiği durumlara rastlanmıştır. 
Örneğin K71 kodlu kitaba ait bu cümlelerden 'Bir zamanlar on çocuğu olan bir baba vardı'. Sabahları 10 Kişilik kahvaltı hazırlardı'. Her çocuğuna 10 küçük kase, 10 küçük kaşık verirdi' sayma becerisi olarak kodlanırken Her çocuğuna 10 küçük kase, 10 küçük kaşık verirdi.'Cümlesi birebir eşleme ve sayma becerisi olarak her iki kategoride kodlanmıştır.

K25 kodlu kitapta geçen 'Kirpi Kip bir salyangozun yanında büyük, bir ayının yanında küçük, bir farenin yanınadaysa küçücük ama bir karıcanın yanıdaysa aeta bi fil kadra büyüktü.' Cümlesi hem sayma becerisi olarak hem de karşılaştırma becerisi olarak kodlanmıştır. Aynı kitapta geçen 'Hayır hayır bu hayvanın dört bacă̆l var' cümlesi sayma becerisi olarak kodlanmıştır.

Şekil 1'de K71 kodlu kitapta resimlere ilişkin kodlamalar yapılırken metin ve resim bağlantısı kurularak metinde geçen "sabahları 10 kişilik kahvaltı hazırlardı" cümlesinden yola çıkarak resimde 10 çocuk ve 10 kase resmedildiği görülmektedir. Bu durumda söz konusu resim hem 10 çocuk ve 10 kase içermesi bakımından sayma becerisine, hem de her çocuğa bir kase düşmesi bakımından eşleştirme becerisine örnek olarak kodlanmıştır.

Örneklerde de belirtildiği gibi kitaplarda geçen cümleler, her bir beceri türü için ayrı ayrı değerlendirilmiştir.

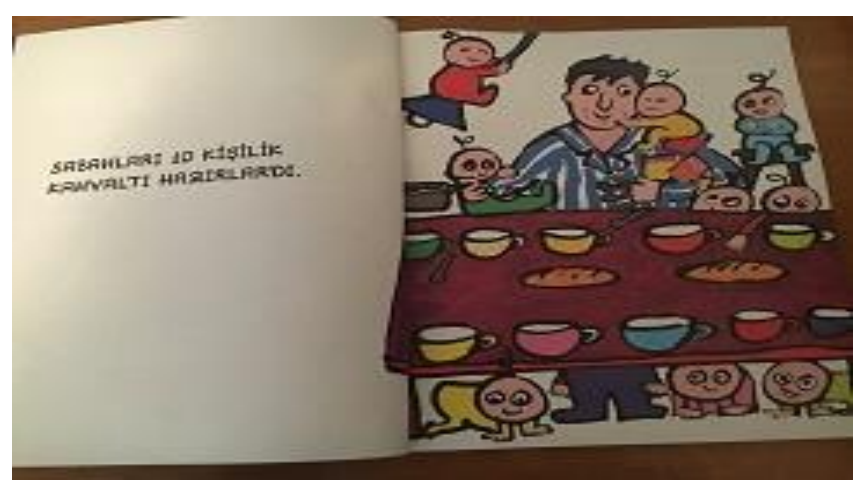

Şekil 1. K71 Kodlu Kitaptan Örnek Resim

İncelenen resimli öykü kitaplarının yayımlandıkları yıllara göre dağılımı Tablo 1'de sunulmuştur.

Tablo 1.

Resimli Çocuk Kitaplarının Yayınlandıkları Yı1lara Göre Dağılımı

\begin{tabular}{|c|c|c|}
\hline Yayın Yili & $\mathrm{N}$ & $\%$ \\
\hline 2005 & 2 & 1.36 \\
\hline 2006 & 1 & 0.68 \\
\hline 2007 & 3 & 2.04 \\
\hline 2008 & - & 0.00 \\
\hline 2009 & 18 & 12.24 \\
\hline 2010 & 9 & 6.12 \\
\hline 2011 & 6 & 4.08 \\
\hline 2012 & 12 & 8.16 \\
\hline 2013 & 9 & 6.12 \\
\hline 2014 & 11 & 7.48 \\
\hline 2015 & 25 & 17.00 \\
\hline 2016 & 35 & 23.80 \\
\hline 2017 & 16 & 10.88 \\
\hline Toplam & 147 & 100 \\
\hline
\end{tabular}


Araştırmada incelenecek resimli öykü kitaplarının temel matematik becerilerini ne düzeyde içerdiğini belirlemek amacıyla, araştırmacılar tarafından 'Kitap İnceleme Formu' oluşturulmuştur. Kitap İnceleme Formu oluşturulurken alan taraması yapılmıştır. Alan taraması yapılırken kullanılan kaynaklar; okul öncesi matematik eğitimi ile ilgili yazılmış yerli, yabancı kitaplar, makaleler, tezler; Milli Eğitim Bakanlığı Okul Öncesi Eğitimi Programı Kitabı (MEB, 2013) ve NCTM (NCTM, 2006) ilke ve standartları olarak belirlenmiştir. Yapılan alan taraması sonucunda temel matematik becerileri sayı kavramının temelini oluşturan birebir eşleme, sınıflama-gruplama, karşılaştırma, sıralama ve sayma becerileri ile sınırlı tutulmuştur. Geliştirme aşamasında literature taraması dışında dört okul öncesi eğitimi alan uzmanı ve bir ölçme değerlendirme uzmanının görüşlerine de başvurulmuştur.

Kitap İnceleme Formu beş bölümden oluşmaktadır. Birinci bölüm, kitabın fiziksel ve içeriksel özelliklerinin ele alındığı bölümdür. İkinci bölümde incelenecek kitapların metin kısmında yer alan temel matematik becerilerinin kitaplarda var olup olmadığ ile ilgili bilgiler yer almaktadır. Üçüncü bölümde, ikinci bölümde tespit edilen temel matematik becerinin kitapların metin kısmında ne düzeyde yer verildiğine ilişkin alıntılar kaydedilmektedir. Dördüncü bölümde, temel matematik becerilerinin incelenen kitapların resim bölümlerinde ne düzeyde yer aldığı varyok şeklinde kodlanmaktadır. Beşinci bölümde incelenen kitapların resim bölümünde tespit edilen bu becerilerin resimlerde belirtilmesine ilişkin kayıtlar tutulmaktadır.

Elde edilen verilerin analizinde betimsel analize başvurulmuştur. Verilerin analizi ve yorumlanması için betimsel analizi yöntemi ile toplanan veriler dört aşamadan geçerek sistemli verilere dönüştürülmüştür. Öncelikle betimsel analiz için bir çerçeve ortaya koymak amacıyla 'Kitap İnceleme Formu' oluşturulmuştur. Betimsel analizin ikinci aşaması ise belirlenen çerçeveye göre verilerin işlenmesi aşamasıdır. Bu aşamada daha önce oluşturulan çerçeveye göre elde edilen veriler okunarak düzenlenmiştir. Ayrıca bu aşamada daha sonra sonuçlar yazılırken kullanılacak doğrudan alıntılar da seçilmiştir. Kitap İnceleme Formu incelenen tüm kitaplar için doldurularak veriler düzenlenmiştir. Ayrıca bu düzenleme yapılırken daha sonradan kullanılacak olan alıntı ve resimler kaydedilmiștir. Üçüncü aşama olan bulguların tanımlanmasında elde edilen veriler kolay ve anlaşılır bir dille tanımlanıp gereksiz tekrarlardan kaçınılarak kaydedilmiştir. En son aşama bulguların yorumlanması aşamasıdır. Bu aşamada resimli öykü kitapları incelenirken her ne kadar kitaplar bir bütün olarak ele alınmaya çalışıldıysa da resim ve metin kısımlarında temel matematik becerileri ayrı ayrı ele alınmıştır (Yıldırım ve Şimşek, 2016). Ölçüt örnekleme gereğince araştırmada incelenen kitapların resim veya metin kısımlarında yer verilen matematik becerileri temel alındığından verilerin analizi metin kısımlarına ilişkin hesaplamalar için 147; resim kısımların da ise 144 kitap üzerinden yapılmıştır. Araştırma verilerinin analizi ve yorumlanmasında frekans ve yüzde analizleri Microsoft Excel 2016 programı kullanılarak yapılmıştır.

Geçerlilik ve güvenirlik: Kitap İnceleme Formu'nun inandırıcılık ve aktarılabilirliğe ilişkin olarak nitel araştırmalarda ölçümlerin inandırıcı olduğuna dair kanıt sunmak amacıyla kodlayıcılar arası inandırıcılık katsayısı hesaplanmıştır. Bu ölçme işleminin inandırıcılığ hesaplamak amacıyla ise kitapların bir kısmı araştırmacı dışında beş farklı okul öncesi eğitim alanında uzman kişiye verilmiş ve kodlayıcılar arası inandırıcılık Krippendorff's alfa katsayısı ile hesaplanmıştır. Krippendorff's alfa katsayısına ilişkin formül aşağıdaki gibidir,

$$
\propto=1-\frac{D_{0}}{D_{e}}
$$

Araştırmada Krippendorff's alfa katsayısının hesaplanması için SPSS 22 programı ve Hayes ve Krippendorff'a (2007) ait syntax kullanılmıştır. Sonuç olarak kitapların metin bölümü için kodlayıcılar arası inandırıcılık katsayısı .87, resim bölümü için kodlayıcılar arası güvenirlik katsayısı ise .85 bulunmuştur. Görüldügüü üzere her iki bölüm için de Krippendorff's alfa katsayısı .66'dan büyüktür. Bu doğrultuda kitaplara ait hem metin hem resim bölümlerinde kodlayıcılar arası inandırıcılık yüksektir ve bu kodlayıcılar arası yüksek uyum olduğunun bir göstergesidir (Krippendorff, 2004, s. 241). 
Ölçümlerin aktarabilirlik aşamasında amaca hizmet etmek adına süreç en başından itibaren uzman görüşleri doğrultusunda planlanmıştır. Yine aktarılabilirliği arttırmak amacıyla ayrıntılı betimlemeler yapılmıştır. Tutarlık ve teyit incelemesi ile de iç ve dış inandırıcılık kanıt sunmak amaçlanmış ve bu doğrultuda araştırmanın tamamını, araştırma verilerini ve sonuçlarını başka bir uzmanın daha incelemesi sağlanmıştır. Aktarılabilirliğe ilişkin bir kanıtta araştırmacının uzun süreli etkileşim stratejisi bağlamında kitaplarla uzun süreli etkileşim içinde olması gerekmektedir. Aktarılabilirliğe desteklemek üzere aynı metinler araştırmacı tarafından kodlandıktan sonra kodlamaların kontrol edilmesi için ikinci kez tüm veriler gözden geçirilmiştir. Böylece veriler üzerindeki araştırmacının öznel algısının etkisi azaltılmıştır. Ayrıca araştırmacının alanda uzun bir süredir çalışıyor olması da derinlik odaklı veri toplama stratejisi bağlamında aktarılabilirliğe kanıt sunmaktadır (Yıldırım ve Şimşek, 2016). Inandırıcılık ve Aktarılabilirlik analizleri sonucunda son halini alan forma, incelenen her kitap araştırmacı tarafından tek tek tek kaydedilmiştir.

\section{Bulgular}

Bu çalışmada amaç, resimli öykü kitaplarının resim ve metin kısımlarında temel matematik becerilerine ne derece yer verildiğini tespit etmektir. Bu amaç doğrultusunda elde edilen bulgular aşağıda araştırmanın amaçları doğrultusunda sunulmuştur.

Tablo 2.

Resimli Öykü Kitaplarının Metin ve Resim Kısımlarında Becerilere Yer Verme Durumunun Dağılımı

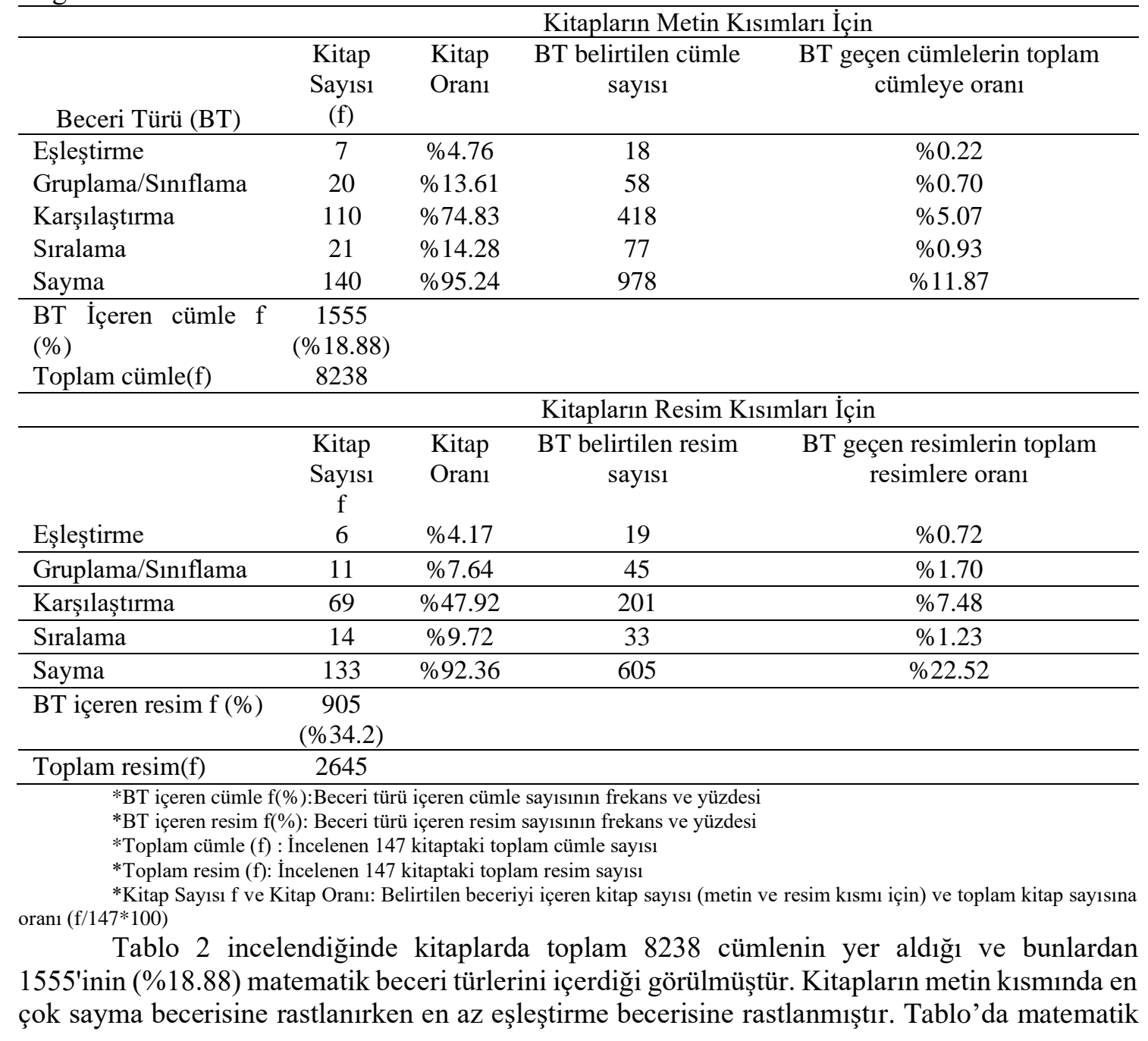


becerileri ayrı ayrı incelendiğinde resimli öykü kitapları içerisinde sadece yedi (\%4.76) kitapta birebir eşlemeyi içeren cümlelerin olduğu görülmektedir. Bu kitaplar içerisinde de sadece 18 cümlenin bu beceriye ilişkin olduğu ve birebir eşleme içeren cümle sayısının toplam cümlelerin $\% 0.22$ 'sini oluşturduğu belirlenmiş̧ir. İncelenen resimli öykü kitaplarının metin kısımlarında rastlanan birebir eşleme becerisi aşağıda verilen örneklerle desteklenmektedir.

K32'de geçen 'Herkes montuyla aynı renkte olanları seçip giysin' ve 'Pembeli mavi, kuzucuk yeşil, benekli ise turuncu renkli olanlarl seçti şimdi bere, atkl ve eldivenleri montlarıyla aynı renkte olmuştu' cümlelerinde birebir eşleme açıkça görülmektedir. K86' da birebir eşleme 'Işste buldum dedi Pote seninmiş o diş izi' cümlesinde görülmüştür.Kitabın konusunda yer alan elmadaki diş izinin kime ait olduğunu tespit etmeye çalışan öykünün kahramanı kitabın sonuç bölümünde elmadaki diş izleriyle diş izinin kime ait olduğunu eşleștirerek bulmuştur.

İncelenen öykü kitaplarından sadece 20'sinde (\%13.61) gruplama/sınıflamaya ilişkin cümleler bulunduğu görülmektedir. Bu kitapların metin kısımları incelendiğinde gruplamasınıflama içeren toplam 58 cümle olduğu ve bu beceriyi içeren cümle sayısının toplam cümlelerin $\% 0.70$ 'ini oluşturduğu belirlenmiştir. Resimli öykü kitaplarında rastlanan gruplama-sınıflama becerisi aşağıda verilen örneklerle desteklenmektedir.

K66'da geçen 'Büyük köpekleri de severim küçük köpekleri de', 'Oyuncu köpekleri de oyun sevmeyen köpekleri de çok severim', Yavaş koşan köpeklerde hızlı koşan köpeklerde çok güzel gelir bana' cümlelerinde köpekleri büyük-küçük köpekler; oyunu seven ve oyunu sevmeyen köpekler; yavaş koşan ve hızlı koşan köpekler olarak gruplandırmıştır. Aynı şekilde K103'te geçen 'Straya girmeden servise binen inenleri, birbirini itenleri, çantalara basarak geçenleri, emniyet kemerlerini takmayanları, saç çekip sakız balonu patlatanları görürsem düdüğ̈̈ çalacağım' cümlesi de gruplama-sınıflama becerisine örnektir.

Karşılaştırma becerisine ilişkin bulgular incelendiğinde ise, incelenen öykü kitaplarının 110 'unda (\%74.83) karşılaştırma içeren cümleler bulunduğu görülmektedir. Bu kitapların metin bölümleri incelendiğinde 418 cümlenin karşlaş̧ırma becerisi içerdiği ve karşılaştırmaya ilişkin cümle sayısının, toplam cümlelerin \%5.07'ini oluşturduğu belirlenmiştir. Resimli öykü kitaplarında rastlanan karşılaştırma becerisi aşağıda verilen örneklerle desteklenmektedir.

K25'te geçen 'Fare kirpi kipten daha küçüktü, çünkü ayi bile filin yaninda küçücük kalirdi. O bu filin yaninda çok çok küçük kalmişti'. Cümlelerinde karşılaştırma becerisi çok net görülmektedir. Aynı durum K89' da geçen 'Hangi canavarın daha çok gözü var? Bu arkadaşımda 5 tane salyangoz var bu arkadaşımda ise daha çok' cümleleri içinde geçerlidir.

Suralama becerisi incelendiğinde ise, öykü kitaplarının sadece 21'inde (\%14.28) sırlamaya ilişkin ifadeler bulunduğu görülmüştür. Bu kitapların metin bölümlerinde 77 cümlenin sıralama becerisi içerdiği ve bu beceri türünün geçtiği cümlelerin toplam cümlelere oranının $\% 0.93$ olduğu belirlenmiştir. İncelenen resimli öykü kitaplarında rastlanan sıralama becerisi aşağıda verilen örnek cümlelerle desteklenmektedir.

K37'deki sıralama cümlesinde 'Erkek doğan bir bebek de büyüdükçe erkek çocuk genç erkek yetişkin erkek orta yaşlı erkek en sonunda da yaşlı erkek olur' genç, yetişkin, orta yaş, ihtiyarlık kelimelerinin oluşturduğu sıralama durumu söz konusudur.

Kitapların metin kısmı için son olarak sayma becerileri incelendiğinde ise, öykü kitaplarının 140'ında (\%95.24) sayma becerisine ilişkin cümleler olduğu görülmektedir. Bu kitapların metin bölümlerinde 978 cümlenin sayma becerisi ile ilgili olduğu ve kitaplardaki toplam cümle sayısının \%11.87'ini sayma becerilerini içeren cümleler olduğu bulunmuştur. İncelenen resimli öykü kitaplarında rastlanan sayma becerisi aşağıda verilen örnek cümlelerle desteklenmektedir.

K18'de geçen 'Üç küçük tilki kocaman dağın eteğine gizlenmiş', 'íki kocaman kulak', 'Daha önce hiç böyle uzun ve garip kuyruklu bir tavşan görmedim' cümlelerinde sayma becerisi açıkça görülmektedir. Ayrıca K135'te Yatağımın altında bir timsah var', cümlesinde sayma becerisine rastlanmıştır.

Tablo 2 incelendiğinde kitaplarda toplam 2645 resmin yer aldığ 1 ve bunlardan 905 'inin $(\% 34,22)$ matematik beceri türlerini içerdiği görülmüştür. Kitapların resim kısmında metin kısımlarına benzer olarak en çok sayma becerisine rastlanırken en az eşleştirme becerisine 
rastlanmıştır. Tablo 2'de kitapların resim kısmı için matematik becerileri ayrı ayrı incelendiğinde sadece $6(\% 4.17)$ kitapta birebir eşlemeye ilişkin görsel bulunduğu görülmektedir. Bu kitaplardan da sadece 19'unda bu beceriye ilişkin resim olduğu ve bu beceriyi içeren resim sayısının toplam görsellerin \%0.72'sini oluşturduğu bulunmuştur. İncelenen resimli öykü kitaplarının resim kısımlarında rastlanan birebir eşleme becerisi aşağıda verilen örneklerle ortaya konmuştur.

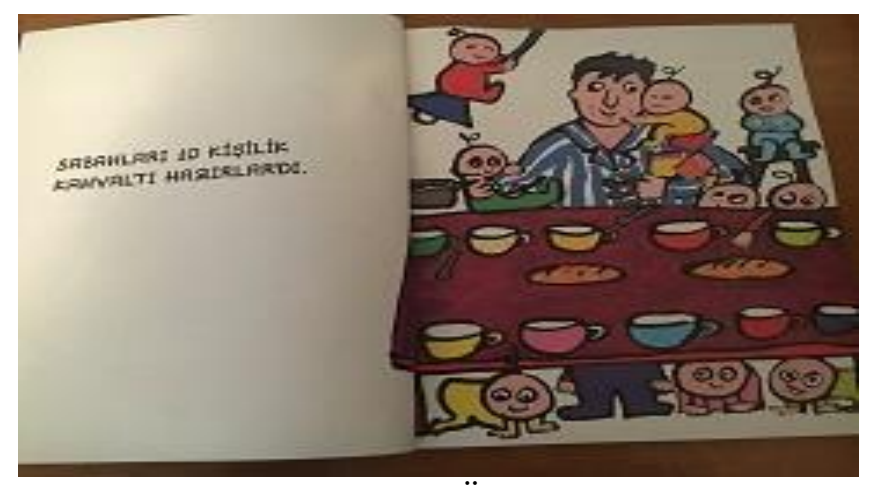

Şekil 1.K71 Kodlu Kitaptan Örnek Resim

K71 kodlu kitapta Şekil 1'de görüldüğüü üzere bir masa etrafında 10 çocuk ve 10 kahvaltı kasesi resmedilmiştir. Her çocuğa bir kase düşmekte olup birebir eşleme becerisi görselle desteklenmektedir.

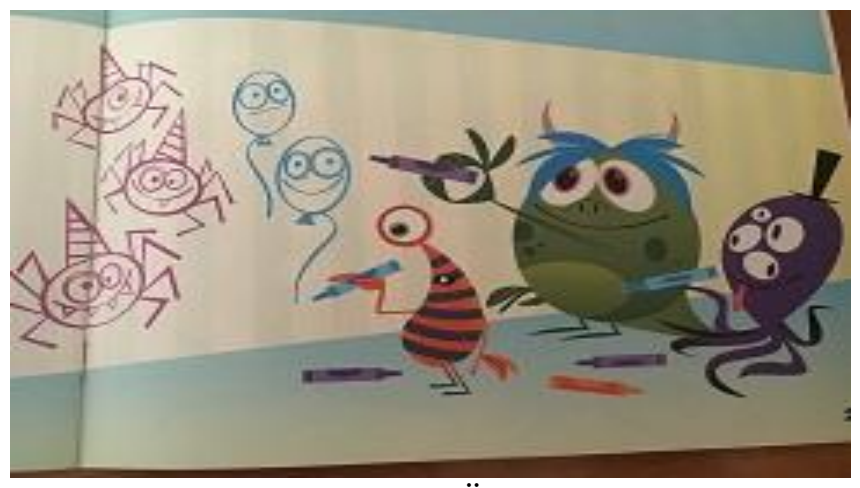

Şekil 2. K89 Kodlu Kitaptan Örnek Resim

Şekil 2'de K89 kodlu kitaptan alınan örnekte üç canavar ve altı kalem bulunmaktadır. Yani eşit olmayan iki küme vardır. Üç canavar her biri eline üç kalem alarak birebir eşleme becerisi ortaya çıkmıştır. Görsele baktığımızda üç canavar ve altı kalem görülmektedir. Her canavarın eline bir kalem alıp resim çizdiği görülmektedir. Canavarlar ve kalemler birebir eşleşmiş olduğu görülmektedir.

K86'daki kitabın kahramanı başına düşen elmayı kimin ısırdığını bulmaya çalışırken elmadaki diş izini çeşitli hayvanların diş iziyle karşılaştırdıktan sonra kitabın sonuç bölümünde elmadaki diş iziyle ait olduğu hayvanın dişlerini 'İşte buldum dedi. Pote, seninmiş bu diş izi' metiniyle de destekleyerek birebir eşleme becerisine örnek oluşturmuştur.

İncelenen oluşturan 147 kitaptan 11 'inde (\%7.64) gruplama/sınıflamaya ilişkin görseller olduğu görülmektedir. Bu kitapların içerisinde 45 resmin gruplama içerdiği ve bu beceri dikkate alındığında toplam resimlerin \%1.70'ini gruplama içeren resimlerin oluşturduğu belirlenmiştir. İncelenen resimli öykü kitaplarının resim kısımlarında rastlanan gruplama-sınıflama becerisi aşağıda verilen örneklerle desteklenmektedir. 


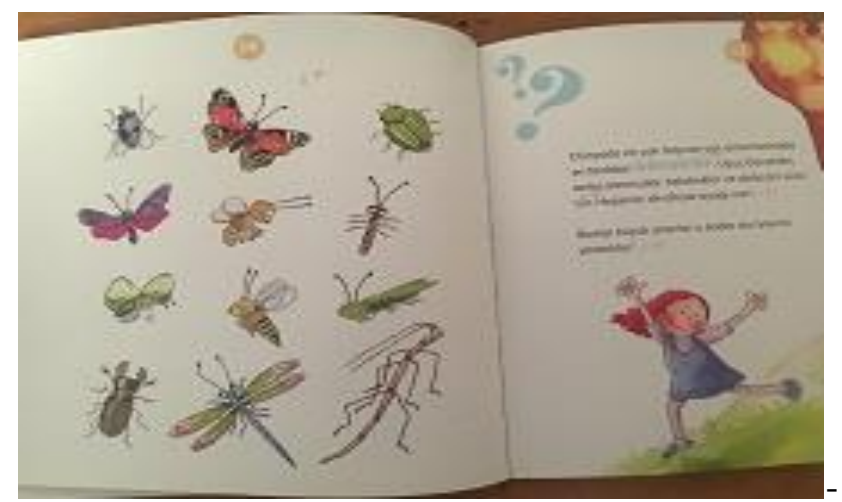

Şekil 3. K76 Kodlu Kitaptan Örnek Resim

K76'dan alınan örnek resimlerde (Şekil 3) görüldüğ̈̈ üzere altı bacaklı böcekleri, ortak özellikleri olan bacak sayısına göre sınıflandırmıştır.

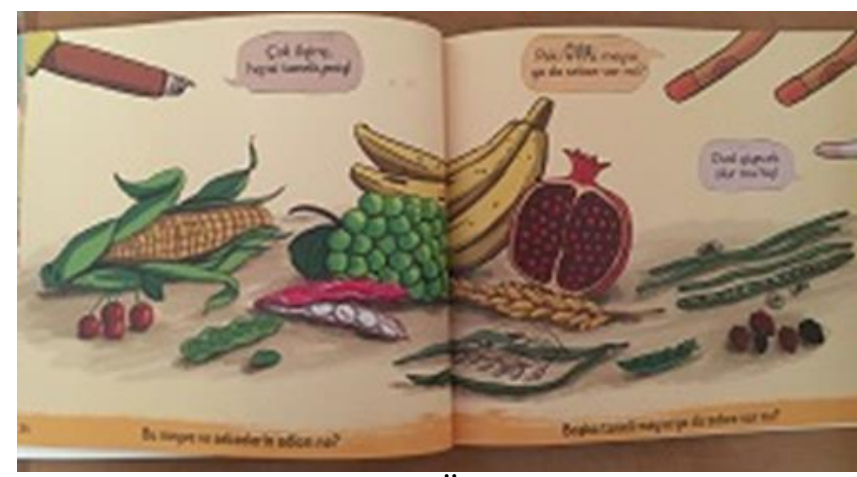

'Çok ilginç hepsi taneliymiş’

Şekil 4. K3 Kodlu Kitaptan Örnek Resim

K3'teki örnek resimde (Şekil 4) görüldüğ̈̈ üzere ortak özellik olarak taneli olmak belirlenmiş ve taneli meyve ve sebzelerden bir gruplama yapılmıştır.

Tablo 2 incelendiğinde resimli öykü kitaplarından 69'unda (\%47.92) karşılaştırma becerisine ilişkin cümleler bulunduğu görülmektedir. Bu kitapların resim bölümlerinde 201 görselin karşılaştırma becerisi ile olduğu ve kitaplarda karşılaştırma becerisi içeren resimlerin, toplam resimlerin \% 7.48'ini oluşturduğu belirlenmiştir. İncelenen resimli öykü kitaplarının resim kısımlarında rastlanan karşılaştırma becerisi aşağıda verilen örneklerle ortaya konmuştur.

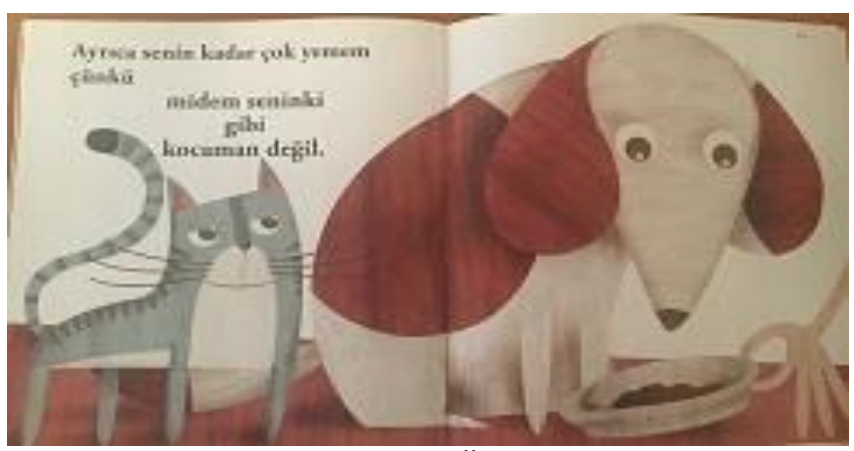

Şekil 5. K94 Kodlu Kitaptan Örnek Resim

K94 kodlu kitaba ilişkin Şekil 5'de görüldüğü üzere kedi ve köpek yanyana durur vaziyette aralarındaki boyut farkıda oldukça görünür vaziyette ve kedi köpeğe 'Midem seninki gibi kocaman değil, diyerek karşılaştırma becerisini desteklediği görülmektedir. 


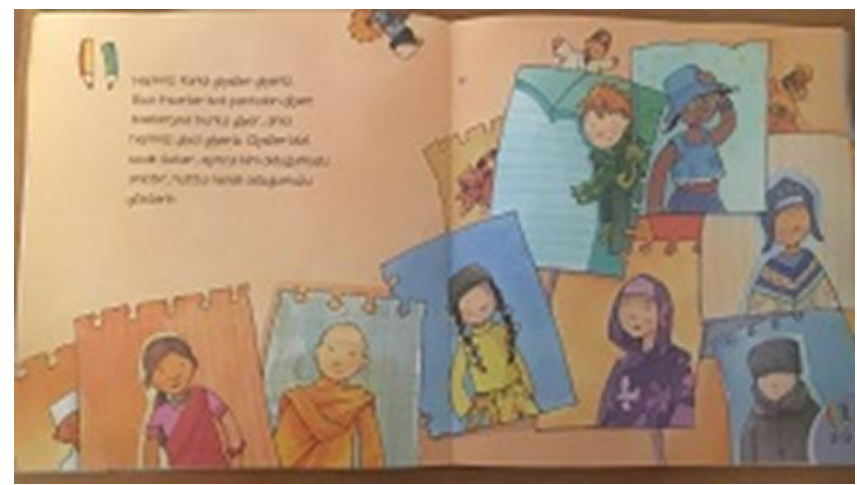

'Hepimiz farkl giysiler giyiniriz. Bazı insanlar kot pantolon giyer; bazllarlysa burka giyer, ama hepimiz giysi giyeriz. Giysiler bizi sicak tutar, ayrica kim olduğumuzu anlatır, hatta nereli olduğumuzu'

Şekil 6. K79 Kodlu Kitaptan Örnek Resim

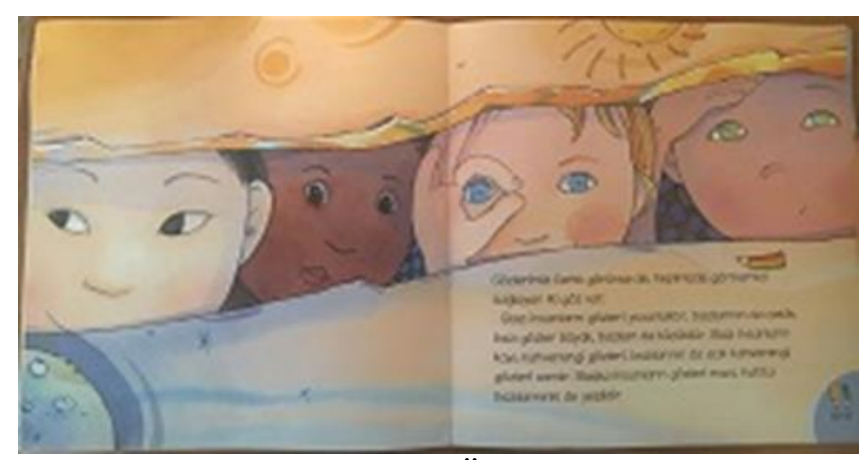

'Gözlerimiz farkl görünse de hepimizde görmemizi sağlayan iki göz vardır'

Şekil 7. K79 Kodlu Kitaptan Örnek Resim

K79 kodlu kitaba ilişkin Şekil 6 ve 7'de insanlar karşılaştırılarak farklı özelliklerinden bahsedilmektedir. $\mathrm{Bu}$ örneklerde karşılaştırma becerisini ön plana çıkarmakta ve metinleri tarafından desteklenmektedir.

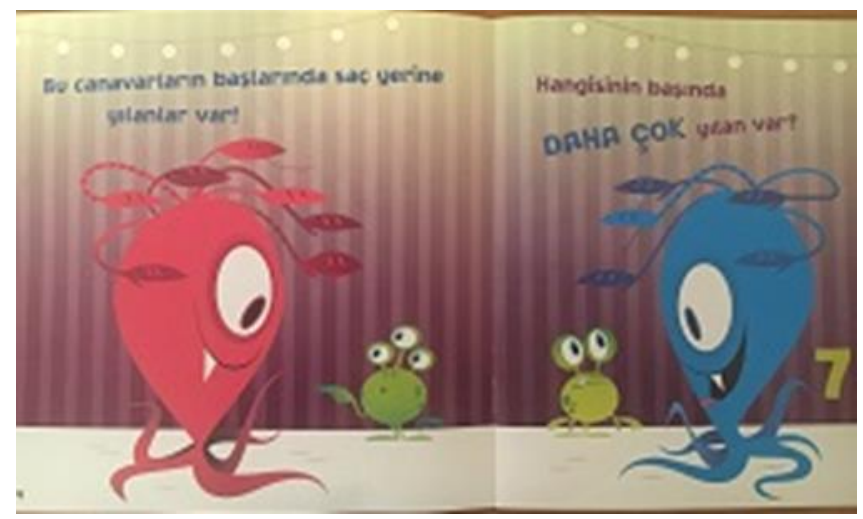

'Bu canavarların başında saç yerine yllan var! Hangisinin başında DAHA ÇOK yılan var?'

Şekil 8. K20 Kodlu Kitaptan Örnek Resim

K20 kodlu kitaba ilişkin Şekil 8'de görüldüğü üzere iki canavarın başındaki yılanların sayısı karşılaştırılarak metinde geçen 'Hangisinin başında DAHA ÇOK yılan var?' sorusuna yanıt aranmıştır.

Sıralama becerisi incelendiğinde, öykü kitaplarından 14'ünde(\%9.72) siralama becerisine yönelik cümleler bulunduğu görülmüştür. Bu kitapların resim bölümlerinde toplam 33 görselin sıralama becerisi içerdiği ve toplam resimlerin \%1.23'ünün sıralama içeren görseller olduğu belirlenmiştir. İncelenen resimli öykü kitaplarının resim kısımlarında rastlanan sıralama becerisi aşağıda verilen örneklerle desteklenmektedir. 


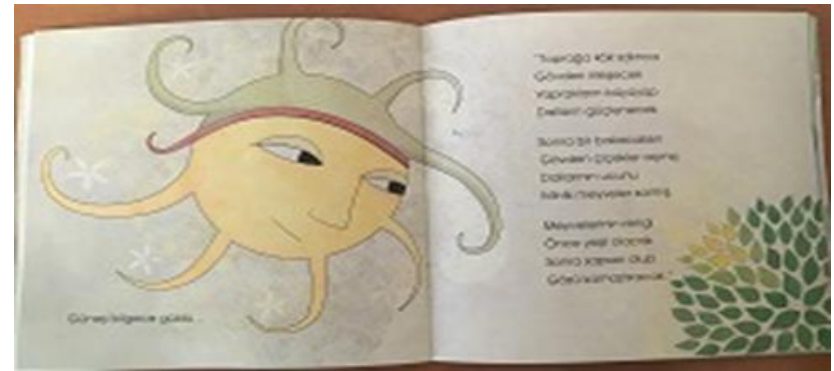

Şekil 9. K54 Kodlu Kitaptan Örnek Resim

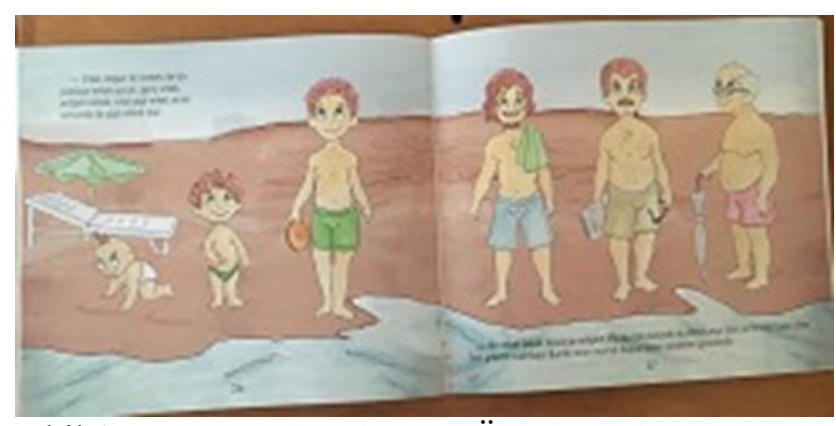

Şekil 10 .K54 Kodlu Kitaptan Örnek Resim
'Meyvelerin rengi önce yeşil olacak sonra sapsarı olup gözü kamaştıracak'

K54 kodlu kitaba ilişkin Şekil 9 ve 10'da yer alan resimlerinde suralama becerileri görülmektedir. Bu örnekler zaman kavramına ilişkin örneklerdir.

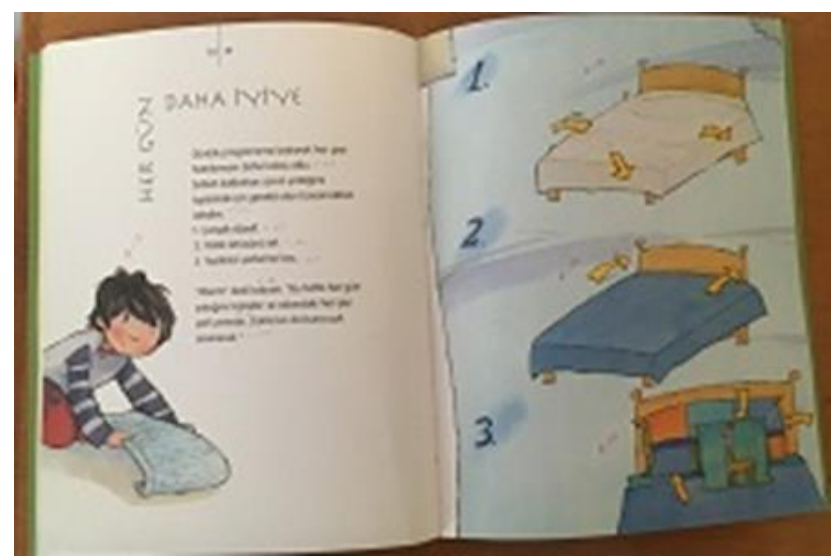

'Erkek doğan bebek büyüdükçe erkek çocuk, genç erkek, yetişkin erkek, orta yaşlı erkek ve en sonun da yaşlı erkek olur'

Şekil 11. K104 Kodlu Kitaptan Örnek Resim

K104 kodlu kitaptan alınan Şekil 11'de görüldüğ̈̈ üzere yatağı düzeltme işlemi belli bir sıra ile birinci, ikinci, üçüncü sıralama kelimeleri kullanılarak yapılmıştır.

Resim kısmı için son olarak öykü kitaplarının 133'ünde (\%92.36) sayma becerisine ilişkin cümleler bulunduğu görülmektedir. Bu kitapların resim bölümlerinde 605 görselin sayma becerisine içerdiği ve sayma becerisine ilişkin resimlerin toplam resimlere oranının \%22.52 olduğu belirlenmiştir. İncelenen resimli öykü kitaplarının resim kısımlarında rastlanan sayma becerisi aşağıda verilen örneklerle desteklenmektedir. 


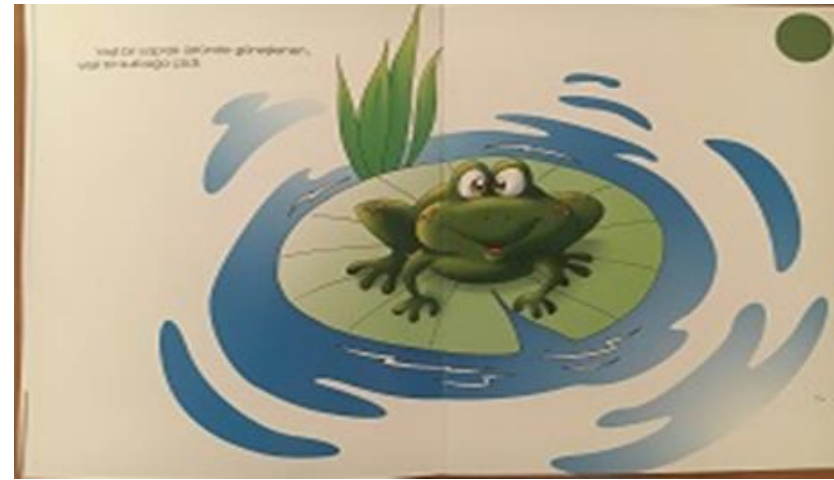

Şekil 12. K58 Kodlu Kitaptan Örnek Resim

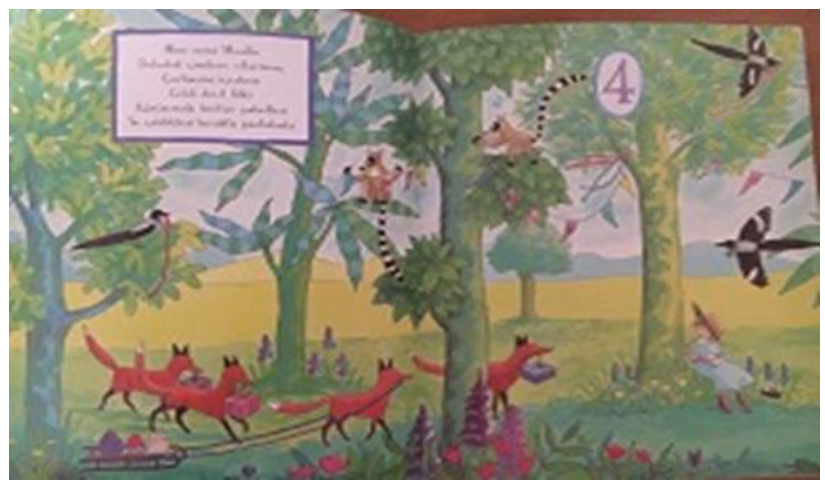

Şekil 13. K10 Kodlu Kitaptan Örnek Resim

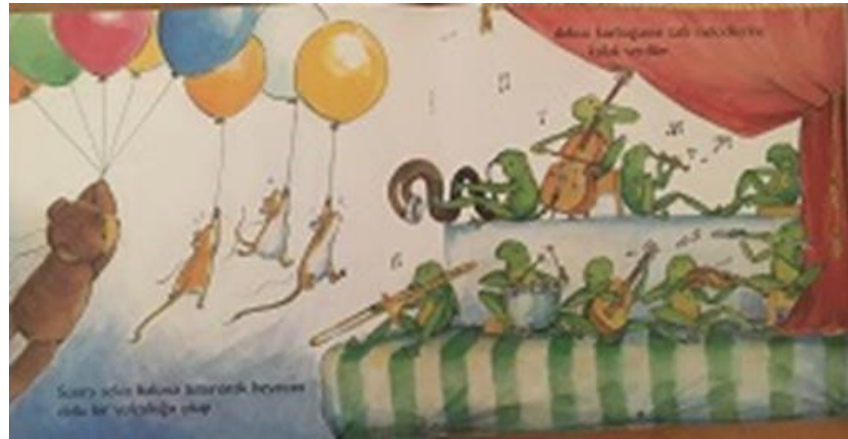

Şekil 14. K136 Kodlu Kitaptan Örnek Resim
'Yeşil bir yaprak üzerinde güneşlenen yeşil bir kurbağa çizdi'

'Mini mini mualla pofuduk çimlere oturmuş, çorbasını içerken geldi dört tilki ăgızlarında hediye paketleri ve çektikleri kızakta pastalarla'

'Sonra sekiz balona tutunarak heyecan dolu bir yolculuğa çıkıp dokuz kurbağanın tatl melodilerine kulak verdiler' Sayma becerisine ilişkin örneklerdir.

Tablo 3.

Resimli Öykü Kitaplarında Temel Matematik Becerilerine Yer Verilmesine Rağmen Çocuğun Gelişimsel Özelliklerini Olumsuz Etkileme Bulunma Durumu

\begin{tabular}{|c|c|c|}
\hline \multirow{2}{*}{$\begin{array}{l}\text { Kitaplarda BT olmasına } \\
\text { rağmen çocukların } \\
\text { gelişimsel özelliklerini } \\
\text { olumsuz etkileyen durum }\end{array}$} & Kitap Say1s1 & Toplam Kitap Sayısına Oranı \\
\hline & 9 & $\% 6.12$ \\
\hline Toplam Kitap Sayıs1 & 147 & \\
\hline
\end{tabular}

\section{BT: Beceri Türii}

Toplam Kitap sayısına oranı: Olumsuz öğeler içeren kitap sayısı/toplam kitap sayısı *100 (9/147*100)

Tablo 3'te resimli öykü kitaplarında bulunan resim ve cümleler bir bütün olarak incelendiğinde matematik becerilerinin bulunmasına karşın çocukların gelişim özelliklerini uygun olmayan durumların olduğu da tespit edilmiştir. Bu durumlar sadece dokuz kitapta yer almaktadır. Bu kitaplar K57, K65, K82, K87, K90, K93, K114, K120 ve K129 kodlu kitaplardır. 
Gelişimler özelliklere uygun olmayan unsurlar içeren kitaplar, toplam kitapların \%6,12'sine karşılık gelmektedir. Bir başka deyişle az da olsa bazı kitaplar çocukların gelişim özelliklerine uygun olmayan unsurlar içermektedir.

İncelenen öykü kitaplarında çocukların gelişimine uygun olmayan özellikler kitaplardan alınan resimlerle aşağıda örneklendirilmiştir.
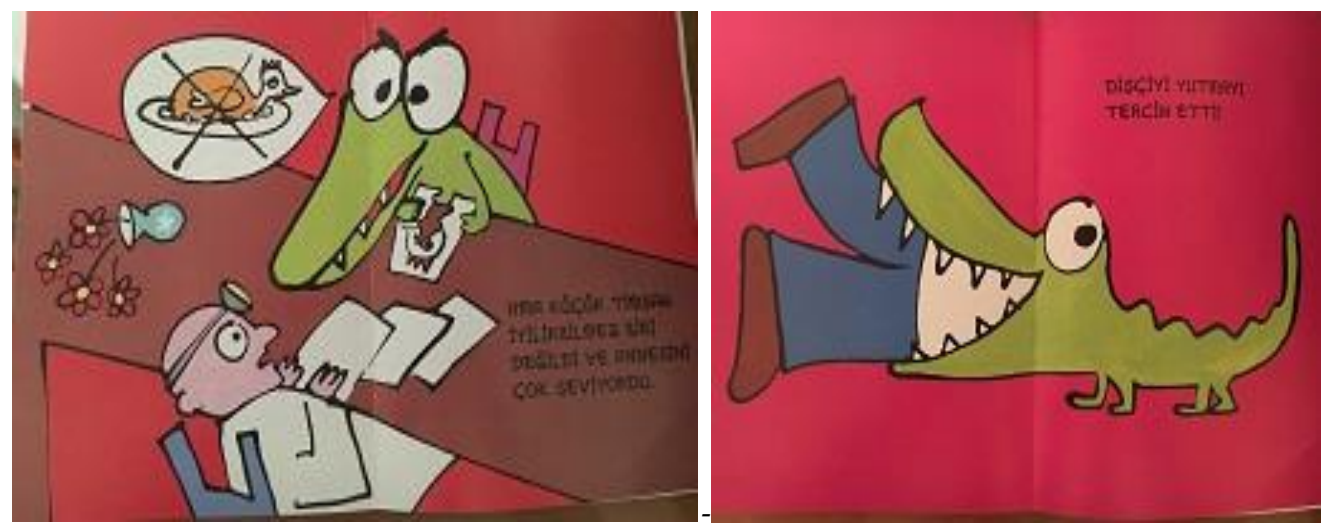

Şekil 15. K90 Kodlu Kitaptan Örnek Resim

K90 kodu kitapta Şekil 15'de yer alan görsellerde görüldüğü üzere öykünün kahramanı timsah hoşuna gitmeyen bir cümle kurduğu için dişçiyi yutmayı tercih etmiştir. Burada çocuklara yanlış mesaj verildiği ve gelişimsel özelliklerini olumsuz etkileyeceği görülmektedir.

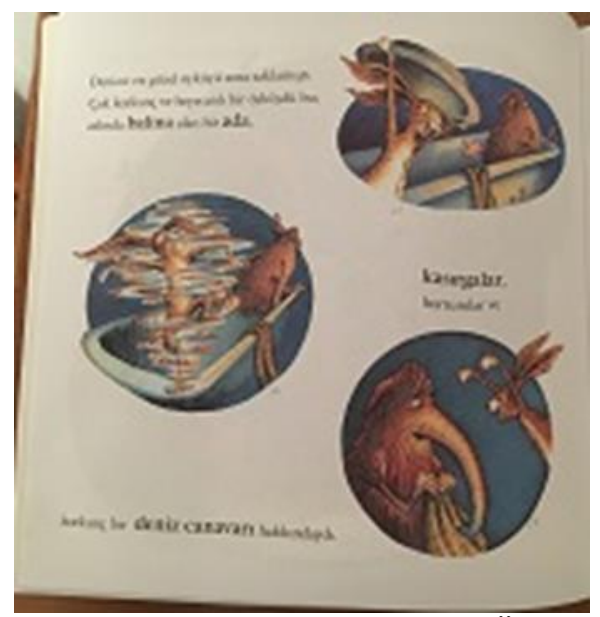

'Kasırgalar hortumlar ve korkunç bir
deniz canavarı hakkındaydl'

Şekil 16. K120 Kodlu Kitaptan Örnek Resim

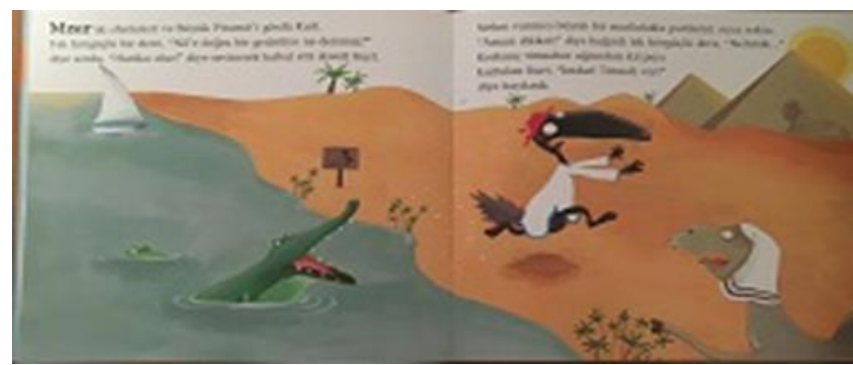

'Korkunç bir timsahın ăgzından kıl payı kurtulan Kurt 'imdat timsah var diye bağırdı,

Şekil 17. K120 Kodlu Kitaptan Örnek Resim

K120 kodlu kitaba ilişkin Şekil 16 ve K87'ye ilişkin Şekil 17'de geçen metinlerde 'korkunç timsah' ve 'korkunç deniz canavarı' kelimeleri korku öğeleri barındırmaları bağlamında çocukların gelişimsel özelliklerini olumsuz yönde etkileyeceği söylenebilir. 


\section{Tartışma}

$\mathrm{Bu}$ araştırma ile resimli öykü kitaplarında temel matematik becerilerine kitapların resim ve metin kısımlarına ne düzeyde rastlandığı tespit edilmeye çalışılmıştır. İncelenen resimli öykü kitabının metin kısımlarının \%4.76'sında, resim kısımlarının ise \% 4.17'sinde birebir eşleme becerisine rastlanmıştır. Bir başka deyişle incelenen kitapların çok azında bu beceriye ilişkin unsurlara yer verildiği belirlenmiştir. Benzer çalışmalar incelendiğinde doğrudan birebir eşleme ile ilgili yapılmış çalışmaya rastlanmazken özellikle sayma becerilerine ilişkin olarak çocukların kazanımları ve gelişimlerini inceleyen çalışmaların içerisinde birebir eşlemeye yer verildiği görülmektedir (Aktaş-Arnas, Deretarla-Gül ve Sığırtmaç, 2003; Akuysal Aydoğan ve Şen, 2011; Olkun ve Babacan-Özer, 2013; Olkun, Çelik, Sönmez ve Can, 2014; Olkun, Yeşilpınar ve Kışla, 2014). Bu durum yapılan araştırmayla benzerlik göstermektedir.

İncelenen resimli öykü kitaplarının metin kısımlarında gruplama/sınıflama becerisine \%13.61, resim kısımlarında ise \%7.64 oranında yer verildiği bulunmuştur. Sınıflama; olay veya varlıkları belirlenen özelliklere göre gruplandırma işlemi olarak tanımlanmaktadır. Nitekim Aslan ve Aktaş-Arnas'ın (2010) yaptığı araştırmada da küçük çocukların sınıflama işlemini şekillerin görsel özelliklerine dikkat ederek yaptıkları bu nedenle okul öncesi dönemde görsel materyallerin özellikle resimli öykü kitaplarının matematik kavramlarının öğreniminde önemli bir unsur olduğu ortaya çıkmıştır. Bununla birlikte Kefi, Çeliköz ve Erişen (2013) araştırmalarında 35 okul öncesi öğretmeninin etkinlik planları incelenmiş ve neticede öğretmenlerin çok azının planlarında sinıflama becerisine yer verdiği, bununla birlikte Nuhoğlu ve Ceylan'ın (2012) yaptıkları araştırmada da öğretmenlerin seçtikleri amaçlardan \%19'unun gruplama-sınıflandırma becerisini desteklediği ve sınıflama/gruplama, sayı ve karşılaştırma becerilerinden sonra öykü kitaplarında en çok rastlanan beceri olduğu ortaya çıkmıştır. Yapılan çalışmada kitaplarda gruplama/sınıflama becerisine birebir eşleme becerisine göre daha fazla rastlanmakla birlikte yer verme oranı dikkate alındığında alanda yapılan araştırma sonuçları ile benzer sonuçlar elde edildiği söylenebilir.

Resimli öykü kitapları karşılaştırma becerisi açısından incelendiğinde, metin kısımlarının $\% 74.83$ 'ünde, resim kısımlarının ise \%47.92'sinde bu becerinin ele alındığı belirlenmiştir. OrçanKaçan ve Halmatov (2017) araştırmalarında öğretmenlerin okul öncesi matematik kavram ve becerilerine verdikleri önem sıralanmış ve sonuçta ögretmenlerin ilk sırada sayma becerisini, ikinci olarakta nicelikleri karşılaştırma becerisini ele aldıkları belirlenmiştir. Aynı araştırmada öğretmenlerin görüşüne göre çocukların en çok zorlandığı matematik becerileri de incelenmiş ve sonuçta çocukların ilk sırada sayılar konusunda ardından ölçme ve karşılaştırma becerisinde zorlandıkları belirlenmiştir. $\mathrm{Bu}$ araştırmaya paralel olarak, karşılaştırma becerilerine incelenen kitapların büyük bir kısmında yer verilmesi, çocukların matematik becerilerini kazanmaları açısından bakıldığında oldukça sevindirici bir sonuç olarak görülebilir.

Sıralama becerisi açısından incelenen kitapların metin kısımlarının \%14.28'sinde; resim kısımlarının \%9.72'sinde bu beceriye rastlanmıştır. Sıralama temel olarak nesnelerin ölçülebilen veya ölçülemeyen özelliklerine göre belirli bir düzen içerisinde dizilmesidir. Ölçülebilen özelliklere göre sıralama nesnelerin diğerlerine göre aynı, daha az ya da daha fazla olup olmadığının belirlenmesi ve buna göre düzenlenmesidir. Sıralama becerisinin öğretiminde kullanılan materyallerden öykülerde ve hikaye kartlarında olayları sıralamanın önemli sıralama etkinlikleri arasında olduğu söylenebilir. Dolayısıyla resimli öykü kitapları için sıralama becerisinin öğrenilmesi konusunda gerekli materyallerden biridir denilebilir (Durmuşoğlu, 2013). Alanda yapılan araştırmalar incelendiğinde de Er'in (2008) olay sıralamasına ilişkin olarak zenginleştirilmiş Türkçe etkinlikleri sunduğu çalışması sonucunda, bu etkinliklerin çocukların zaman kavramının gelişimini olumlu yönde etkilediği; Bruce ve Threlfall'ın (2004), üç ve dört yaşındaki çocuklarda sayıların kardinal ve ordinal özelliklerini onlara çeşitli görevler vererek araştırdıkları çalışmalarında sayma becerisinin gelişimi için sıralama becerisinin kazanımının önemli bir yere sahip olduğu bulunmuştur. Bu bağlamda çocuklara sunulan resimli öykü kitaplarının içerisinde önemli matematik becerilerinden biri olan sıralamaya rastlanmış fakat diğer beceri türlerine göre oldukça az yer verildiği görülmüştür.

Resimli öykü kitaplarında sayma becerisine yer verilme durumu incelendiğinde ise metin kısımlarının \%95.24'ünde resim kısımlarını \% 92.36'sında bu beceriye yer verildiği 
görülmektedir. Bir başka ifade ile incelenen kitapların neredeyse hepsinde bu beceriye yer verildiği söylenebilir. Sayı kavramına dair araştırmalar incelendiğinde Casey, Andrews, Schindler, Kersh, Samper ve Copley (2008) çalışmalarında, öykü ve blok kullanarak yapılan matematik etkinliklerinin çocukların sayma becerilerinin gelişimini olumlu yönde etkilediği görülmüştür. Benzer olarak Young-Loveridge (2004) araştırmalarında ise sayma becerilerinin geliştirmek için oyunlar ve sayı kitaplarının kullanıldığı bir programın etkilerinin incelendiği araştırmada oyun ve sayı kitaplarını eğitimlerinde kullanılan grubun kullanmayan gruba göre sayma becerilerinin daha çok geliştiği sonucuna- ulaşılmıştır. Yılmaz Genç, Akıncı-Çoşgun ve Pala (2017) resimli öykü kitaplarında yer alan matematik kavramlarını inceledikleri araştırmalarında da yine kitaplarda en fazla oranda sayı ve işlem kategorisine yer verildiği bulunmuştur. Öğretmenler ile yapılan araştırmalar incelendiğinde de sınıf içinde en çok sayı sembollerini ve sayma kategorisini kullandıkları (Erdoğan, Parbucu ve Boz, 2017), ve etkinlik planlarında en çok sayı kavramını kazanmaya yönelik kazanımlara yer verdikleri (Pekince ve Avc1, 2016) büyük bir kısmının matematik kavramlarını sayılardan ibaret olarak algıladıkları (Tarım ve Bulut, 2006) ortaya çıkmıştır. Bu bağlamda araştırmada incelenen kitapların hemen hepsinde sayma becerisine ilişkin sözcük ve görsellere yer verilmesi oldukça sevindirici bir sonuç olmakla birlikte diğer matematik becerilerinde de bu duyarlılığın gösterilmesi çocukların matematik becerilerinin gelişimi açısından oldukça önemlidir.

Son olarak araştırma kapsamında incelenen resimli öykü kitaplarının \%6.12'sinin temel matematik becerileri bulunmasına rağmen çocukların gelişimlerine uygun olmayan şiddet içerikli sözcük ve görseller de barındırdığı tespit edilmiştir. Çocukların şiddet öğesi barındıran unsurlarla karşılaşması saldırganlığı kişilik özelliğine çevirmesine neden olmaktadır. Resimli öykü kitaplarındaki şiddete ilişkin unsurlar bağırmak, sivri dişler, aşırı kızgın surat ifadesi olarak betimlenebilir. Çocuklar bu tarz görsellerden olumsuz yönde etkilendiğini ortaya koyan birçok araştırma sonucu bulunmaktadır (Çabuk, Baş ve Teke, 2017; Dağlığlu ve Çakmak, 2009; Fırat, Güleç ve Şahin, 2013). Bu bağlamda çocukların sevdikleri materyallerden biri olan öykü kitaplarında onların gelişimini olumsuz etkileyecek bu tür unsurlara az da olsa yer verilmesi, hitap ettikleri grup açısından kabul edilebilir bir durum değildir.

\section{Sonuç ve Öneriler}

Resimli öykü kitaplarının temel matematik becerileri açsından incelenmesi sonucunda kitapların metin kısımlarında, temel matematik becerilerine ait cümlelerin toplam cümlelerin \%18.88'ini oluşturduğu tespit edilmiştir. Resim kısımlarında ise bu becerilere ilişkin görseller tüm görsellerin \% 34.22'isini oluşturduğu belirlenmiştir. Bir başka deyişle kitapların resim kısımlarında metin kısımlarına göre daha fazla matematik becerisine yer verildiği belirlenmiştir. Elde edilen bu sonuç, kitapların hitap ettiği hedef kitle olan okul öncesi dönem çocuklarının özelliklerinin dikkate alındığını göstermekle birlikte, bu konuda yapılan araştırmalar doğrultusunda resimmetin dengesine dikkate edilerek resimlerde belirtilen unsurların metin kısımlarıyla uyumlu olmasının çocukların kavramları kazanmaları açısından oldukça önemli olduğunu akılda tutmak gerektiğini göstermektedir. Bununla birlikte incelenen öykü kitaplarının metin kısımlarında en çok sırasıyla sayma, karşılaştırma, sırlama, gruplama/sıralama ve birebir eşleşme becerilerine yer verildiği; kitapların resim kısımlarında ise en çok sırasıyla sayma, karşılaştırma, gruplama/sınıflama, sıralama ve birebir eşleme becerilerinin ele alındığı görülmüştür. Ayrıca incelenen kitaplardan dokuzunda çocukların gelişimlerine uygun olmayan şiddet içerikli cümle ve görseller bulunduğu da tespit edilmiştir. Bu sonuç, çocukların yüksek yararı düşünüldügünde onların gelişimini olumsuz etkileyecek herhangi bir durumla karşılaşmamaları konusunda oldukça hassas davranılması ve bu bağlamada sorumluluğu olan bütün paydaşların bilinçli olması gerektiğini ortaya koymaktadır. Araştırma, resimli öykü kitaplarının resim ve metin kısımlarında sayı kavramının temelini oluşturan birebir eşleme, sınıflama/gruplama, karşılaştırma, sıralama ve sayma becerileri ve çocukların gelişimlerine uygunluğuna ilişkin unsurların incelenmesi ile sınırlıdır. Bu bağlamda nitel araştırma yöntemi kullanılarak gerçekleştirilen bu araştırmada sonuçların evrene genellenmesi kaygısı bulunmamaktadır. 
Araştırmadan elde edilen bu sonuçlar doğrultusunda resimli öykü kitapları konusunda önce ilgili alan uzmanları, psikologlar ve okul öncesi öğretmenlerinden oluşan bir komisyon tarafından incelenerek yayınevinin kitap basımı konusunda daha titiz davranmaları sağlanabilir. Ayrıca çocuk kitabı yazarları ve çizerlerinin resimli öykü kitaplarının içeriğinde temel matematik kavram ve becerilerine yer verme ve kitaplarda ebeveynlere yönelik yönlendirici bilgiler sunma konusunda alan uzmanlarından destek almaları sağlanabilir. Okul öncesi dönem çocuklarına matematik eğitimi verme konusunda gerek okul öncesi öğretmenleri gerekse aileleri hedef alan uygulamalı seminerler düzenlenmesi önerilebilir. Bu konuda araştırma yapacak kişiler için öykü kitapları kullanılarak temel matematik beceri ve kavramlarının çocuklara kazandırılması konusunda deneysel araştırmalar yapmaları önerilmektedir.

\section{Araştırmanın Etik İzinleri}

Yapılan bu çalışmada "Yükseköğretim Kurumları Bilimsel Araştırma ve Yayın Etiği Yönergesi" kapsamında uyulması belirtilen tüm kurallara uyulmuştur. Yönergenin ikinci bölümü olan "Bilimsel Araştırma ve Yayın Etiğine Aykırı Eylemler" başlığı altında belirtilen eylemlerden hiçbiri gerçekleştirilmemiştir.

\section{Kaynaklar}

Aktaş Arnas, Y. (2002). Okul öncesi dönemde matematik eğitimi. Adana: Nobel.

Aktaş-Arnas, Y. (2013). Okul öncesi dönemde matematik ĕgitimi. Ankara: Nobel.

Aktaş-Arnas, Y., Deretarla- Gül, E. ve Sığırtmaç, A. (2003). 48-86 ay çocuklar için sayı ve işlem kavramları testinin geçerlilik ve güvenirlik çalışması, Çukurova Üniversitesi Sosyal Bilimler Enstitüsü Dergisi, 12(12), 147-157.

Akuysal Aydoğan, S. ve Şen, S. (2011). 6 yaş çocuklarının sayı kavramının gelişiminde kavram eğitim programının etkisinin incelenmesi. Adnan Menderes Üniversitesi Ĕgitim Fakültesi Eğitim Bilimleri Dergisi, 2(1), 38-51.

Angın, D.E. (2013). Proje temelli eğitim programının 60-71 aylık çocukların kavram geliş̧imine etkisi (Doktora tezi). Selçuk Üniversitesi Sosyal Bilimler Enstitüsü, Konya.

Aslan, D. ve Aktaş-Arnas, Y. (2010). Okul öncesi eğitim materyallerinde geometrik şekillerin sunuluşuna ilişkin içerik analizi. Çukurova Üniversitesi Sosyal Bilimler Enstitüsü Dergisi, 16(1), 69-80.

Bruce, B. ve Threlfall, J. (2004). One, two, three and counting. Educational Studies in Mathematics, 55, 3-26.

Casey, B. M., Andrews, N., Schindler, H., Kersh, J. E., Samper, A. ve Copley, J. (2008). The development of spatial skills through interventions involving block building activities. Journal Cognition and Instruction, 26(3), 269-309.

Charlesworth, R. (2005). Prekindergarden mathematics connecting with national standarts. Early Childhood Education Journal, 32(4), 229-236.

Charlesworth, R. ve Lind, K. K. (2013). Math and science for young children. (7th Edition) Wadsworth: Congage Learning.

Çabuk, B., Baş, T. ve Teke, N. (2017). Resimli öykü kitaplarındaki görseller ve metinler masum mu? İletilen doğal çevre mesajları. Bartın Üniversitesi Eğitim Fakültesi Dergisi, 6(3), 984-1016.

Dağlıŏlu, H. E. ve Çamlıbel Çakmak, Ö. (2009). Okul öncesi çocuklarına yönelik yayınlanan hikaye kitaplarının şiddet ve korku öğeler açısından incelenmesi. Türk Kütüphaneciliği 23(3), 510-534.

Dibek, E. (2017). Sayma-sayılar ve işlemler. İ. Ulutaş (Yay. haz.). Okul öncesi matematik eğitimi içinde (ss.105-122). Ankara: Hedef.

Durmuşoğlu, M. C. (2013). Okul öncesi eğitimde bilişsel gelişim ve etkinlikler. Cito Eğitim Kuram ve Uygulama Dergisi, 19(2), 18-30.

Er, H. N. (2008). Zaman kavramiyla zenginleştirilmiş Türkçe dil etkinliklerinin 5-6 yaş çocuklarında zaman kavramı gelişimine etkisinin incelenmesi (Yüksek lisans tezi). Selçuk Üniversitesi Sosyal Bilimler Enstitüsü, Konya. 
Erdoğan, S., Parbucu, N. ve Boz, M. (2017). Sayı ve işlemlerle ilgili eğitim materyallerinin okul öncesi dönem çocuklarının matematik becerisine etkisi. İlkögretim Online, 16(4), 17771791.

Erdoğan, S. ve Baran, G. (2003). Erken çocukluk döneminde matematik. Eğitim ve Bilim, 28 (130), 32-40.

Fırat, H., Güleç, H. ve Şahin, Ç. (2013). Okul öncesi dönem çocuklarına yönelik hazırlanan masal ve öykü kitaplarının korku ve şiddet öğeleri açısından incelenmesi. The Journal of Acadenic Social Science Studies, 6(5), 217-241.

Fırat, Z. S. ve Dinçer, Ç. (2018). Okul öncesi öğretmenlerin matematiksel ifadeleri kullanımlarının incelenmesi. Abant İzzet Baysal Üniversitesi Ĕ̈itim Fakültesi Dergisi, 18(2), 895-914.

Gelman, R. ve Gallistel, C. (1978). The child's understanding of number. Cambridge, MA. Harvard University.

Gönen, M. ve Veziroğlu, M. (2012). Resimli çocuk kitaplarının M.E.B okul öncesi eğitim programındaki kazanımlara uygunluğunun incelenmesi. Eğitim ve Bilim Dergisi, $37(163), 227-238$.

Güneş, F. (2000). Çocuk kitaplarında okunabilirlik ilkeleri. Yaşadıkça Eğitim, 67, 35-40.

Güven,Y.(1997). Erken Matematik Yeteneği Testi-2'nin geçerlik, güvenirlik, norm çalışması ve sosyo-kültürel faktörlerin matematik yeteneğine etkisinin incelenmesi (Yayımlanmamış doktora tezi) Marmara Üniversitesi Sosyal Bilimler Enstitüsü, İstanbul.

Güven, Y. (2002). Erken çocukluk döneminde sezgisel düşünme ve matematik. V.Ulusal Fen Bilimleri ve Matematik Kongresinde sunulmuş bildiri, Orta Doğu Teknik Üniversitesi Okul Öncesi Eğitimi Bölümü, Ankara.

Güven, Y. (2005). Matematik eğitiminde cinsiyet farklılı̆̆ı. M. Sevinç (Yay. haz.) Erken Çocuklukta Gelişim Ve Eğitimde Yeni Yaklaşımlar, içinde (ss. 205-211). İstanbul: Morpa.

Güven, Y. ve Uyanık-Balat, G. (2006). 1. ve 2. Sınıf öğrencilerinin matematik yeteneğinin okul öncesi eğitim alıp almama ve kurunmda veya ailesinin yanında kalma durumlarına göre karşılaştırılması. 1. Uluslararası Okul Öncesi Eğitim Kongresi Bildiri Kitabı 1. Cilt, içinde (ss. 384-397). İstanbul:Ya-Pa.

Hayes, A. F. ve Krippendorff, K. (2007). Answering the call for a standard reliability measure for coding data. Communication Methods and Measures, 1, 77-89.

Hong, H. (1996). Effects of mathematics learning through children's literature on math achievement and dispositional outcomes. Early Childhood Research Quarterly, 11, 477494.

Kandır, A. ve Orçan, M. (2010). Okul öncesi dönemde matematik. İstanbul: Morpa

Kefi, S., Çeliköz, N. ve Erişen, Y. (2013). Okul öncesi eğitim öğretmenlerinin temel bilimsel süreç becerilerini kullanım düzeyleri. Ĕ̈itim ve Öğretim Araştırmaları Dergisi, 2(2), 2146-9199.

Krippendorff, K. (2004). Content analysis: an introduction to its methodology. Thousand Oaks CA: Sage.

Lind, K. K. (2000). Exploring science in early childhood education (3rd.ed.). Albany: Delmar.

Albany Mayer, R. (2004). Should there be a three-strike rule against pure discovery learning? The case for guided methods of instruction. American Psychologist, 59, 14-19.

Lowitt, C. ve Clarke, D. (1992). The mathematics curriculum and teaching program (MCTP): professional development package activity bank. Carlton: Curriculum Cooperation.

Milli Eğitim Bakanlığı (2013). Okul öncesi eğitim programı. Ankara: Milli Eğitim Bakanlı̆̆ı, Temel Eğitim Genel Müdürlüğü.

National Council of Teachers of Mathematics (NCTM), (2006). Curriculum local points for prekindergarden through grade \& mathematics a quest for caberrence. RestonVA: Author.

Nuhoğlu, H. ve Ceylan, R. (2012). Okul öncesi öğretim programında yer alan amaç ve kazanımların bilimsel temel süreç becerileri açısından değerlendirilmesi. Buca Eğitim Fakültesi Dergisi, 34, 112-127. 
Oğuzkan, A. F. (1997). Yerli ve yabancı yazarlardan örneklerle çocuk edebiyatı. 5.Baskı, Ankara: Emel.

Olkun, S., Çelik, E., Sönmez, M. T., ve Can, D. (2014). İlköğretim birinci sinıf Türk öğrencilerinde sayma ilkelerinin gelişimi. Başkent Üniversitesi Eğitim Dergisi, 1(2), 115125.

Olkun, S., Fidan, E. ve Babacan-Özer, A. (2013). 5-7 yaş çocuklarda sayı kavramının gelişimi ve saymanın problem çözmede kullanımı. Eğitim ve Bilim, 38(169), 236-248.

Olkun, S., Yeşilpınar, M. ve Kışla, S. (2014). Birinci sınıf öğrencilerinde kardinalite ve ilişkili kavramların problem durumlarında kullanımı. İlköğretim Online, 13(1), 146-154.

Orçan-Kaçan, M. ve Halmatov, M. (2017). Türkiye'de uygulanan okul öncesi eğitim programında matematik planlama ve uygulama. Pamukkale Üniversitesi Ĕ̈itim Fakültesi Dergisi, 2017(42), 149-161.

Özer, A. (2006). Çocuk kitaplarındaki resimlerin "çocuğa göreliği”. Ankara Üniversitesi Eğitim Bilimleri Fakültesi 2. Ulusal Çocuk ve Gençlik Edebiyatı Sempozyumu (4-6 Ekim 2006), içinde (ss. 425-432). Ankara: Ankara Üniversitesi Yayınları, No:203.

Pekince, P. ve Avc1, N. (2016). Okul öncesi öğretmenlerinin erken çocukluk matematiği ile ilgili uygulamaları: Etkinlik planlarına nitel bir bakış. Kastamonu Eğitim Dergisi, 24(5), 23912408.

Powell, S. R. ve Haag-Nurnberger, J. (2015). Everybody counts, but usually just to 10! A systematic analysis of number representations in children's books. Early Education and Development, 26(3), 377-398.

Rogers, R. M., Coopers, S., Nesmith, S. M. ve Cassidy-Purdum, B. (2015). Ways thet preservice teachers integrate childrens literature into mathematic lessons. The Teacher Educator, 50(3), 170-186. http://doi.org/10.1080/08878730.2015.1038493

Schiro, M. (1997). Integrating children's literature amd mathematics in the classroom: children as meaning makers, problem solvers and literary critics. Newyork: Teachers College.

Sever, S. (2003). Çocuk ve edebiyatı. Ankara: Kök.

Şahin, G. (2014). Okul öncesi dönem çocuk kitaplarında görsel bir uyaran olarak resim. International Periodical for The Languages Literature and History of Turkush Or Turkic, 9(3), 1309-1324.

Tarım, K., ve Bulut, S. (2006). Okul öncesi öğretmenlerinin matematik ve matematik öğretimine ilişkin alg1 ve tutumları. Çukurova Üniversitesi Eğitim Fakültesi Dergisi, 32(3), 152-164.

Tekin, H.(2005). Çocuk edebiyatında şiddet korku ve sevgi üçgeni. Hece Edebiyat Dergisi, 104105, 304-306.

Thomas, N., Mulligan, J.T. ve Goldin, G. A. (2002). Childrens representations and cognitive structural development of the counting sequence 1-100. Journal of Mathematical Behavior, 21, 117-133.

Van Den Heuvel-Panhuizen, M., Van den Boogaard, S. ve Doig, B. (2009). Picture books stimulate the learning of mathematics. Australian Journal of Early Childhood, 34(3), 3039.

Walcott, H. F. (1994). Transforming qualitative data: description, analysis and interpretation. London: SAGE Publications.

Yıldırım, A. ve Şimşek, H. (2013). Sosyal bilimlerde nitel araştırma yöntemleri. (Dokuzuncu bask1), Ankara: Seçkin.

Yıldırım, A. ve Şimşek, H. (2016). Sosyal bilimlerde nitel araştırma yöntemleri. İstanbul: Seçkin.

Yılmaz Genç, M. M., Akıncı Çoşgun, A. ve Pala, S. (2017). A study of mathematical content provided in 1llustrated children's books. Eurasion Journal of Educational Research, 69, 159-175.

Young-Loveridge, J. M. (2004). Effect on early numeracy of a program using number books and games. Early Childhood Research Quarterly, 19(1), 82-98.

\section{Extended Abstract}




\section{Introduction}

In preschool education, activities related to the basic skills of mathematics should be planned to be appropriate to the mental development of children and the learning of new concepts (Kandir $\&$ Orçan, 2010, p. 47). Mathematics education can be given by routine activities, music, table, play, preparing for reading and writing and mother tongue activities (Erdoğan \& Baran, 2003). In the process of education, teacher uses books with the concepts of mathematics as a guide. Especially with the mother tongue activities, it is allowed children to learn the basic mathematics skills. There are many mathematical skills in the language activities such as poems, jokes, riddles, rhymes, finger games and stories which are types of children's literature (Güven, 2002). These mathematical concepts, which are used in mother tongue activities in story, rhymes and finger games and the elaboration of these concepts in story books contribute to the development of mathematical skills. Talking about mathematics in Turkish activities, using mathematical words and concepts and providing the focus of the child on the symbols related to mathematics in the pictures are extremely important for mathematics education (Firat \& Dinçer, 2018).

The aim of picture story books is not to teach mathematics directly; the correct use of mathematical elements within the books is the basis of the thinking about mathematics. While reading books, new pictures and movements related to mathematics appear in children's minds. Children can create positive perceptions of mathematics by combining new learning with previous experiences (Lowitt Clark, 1992).

Before considering the opportunities for the mathematical skills in picture story books prepared for preschool age children, perhaps the most important consideration is to examine whether there are factors that may negatively affect the development of children. When the literature is examined, it is seen that picture story books not only overemphasize friendly feelings that embrace the child with affection, affectionately kiss, rivet the confidence, trust, protect and help but also the feelings of being anxious, fearful and worried as can be overcome (Tekin, 2005, p. 306).

Although it is known that the picture story books are used as educational material, there are few studies examining this subject (Gönen \& Veziroğlu, 2012; Powell \& Haag, 2015; Rogers, Cooper, Nesmith \& Cassidy, 2015; Yılmaz Genç, Akıncı Çoşgun \& Pala, 2017). Therefore, the findings of the research will show the level of the concepts in the basic mathematics books in the picture story books and will guide the more conscious studies in this direction. In this context, the following questions were sought in this research.

1. What is the level of matching, grouping, comparison, sorting and counting skills in the text and picture parts of the picture story books used in preschool period?

2. What is the situation of elements that are not suitable for the development of children in the picture story books?

\section{Method}

In this study, the qualitative research methods were used to determine the extent to which the basic mathematical skills are included in picture story books written for children aged 3-6. In addition, the descriptive survey model, which is a type of screening model, was used in this study. The books examined in the research consisted of published picture story books for children between 36-72 months of age between the year 2005-2017. In the text and/or painting part of the story books, 147 picture story books which contain basic mathematics skills are formed. The books that constitute the study group were firstly divided into picture story books published in bookstores between 2005-2017. Afterwards, books for 36-72 months old children were identified and text and/or painting parts were examined and the books containing basic mathematics skills were separated and 147 books were purchased. The book review form consists of five (5) chapters and was developed by researchers. In this form, the physical and textual features of the picture story books, the picture and text parts of the mathematics skills are included in the level of how and what is included. 
After the books obtained by the researchers were read three times, each book was coded as $\mathrm{K} 1, \mathrm{~K} 2, \mathrm{~K} 3 \ldots$ and recorded in the 'Book Review Form'. The data collected through descriptive analysis method for the analysis and interpretation of the data were converted into systematic data through four stages. Frequency and percentage analyzes were performed by using the Microsoft Excel Program 2016 for the analysis and interpretation of research data.

In order to provide evidence of the credibility of measurements in qualitative research on credibility and transferability of this form, the credibility coefficient between coders was calculated. In order to calculate the transferability of this measurement process, some of the books were given to five different preschool education field and transferability between coders calculated by Krippendorff's alpha coefficient. As a result, the inter-rater reliability coefficient was found to be 87 for the text part of the book; the inter-rater reliability coefficient was found to be 85 for the picture section of the books. At the stage of credibility of the measurements, the process was planned in line with the expert opinions from the very beginning in order for the measurements to serve the purpose.

\section{Result and Discussion}

$4.76 \%$ of the text parts of the picture story book of the picture and $4.17 \%$ of the parts of the picture were one-to-one matched. In the text parts of the picture story books, it was found that $13.61 \%$ of the grouping/classification skills and $7.64 \%$ of the painting parts were included. In the researches, grouping/classification skills in books were found to be more common than matching skills.

When the picture story books were analyzed in terms of comparison skills, $74.83 \%$ of the text part; it was determined that $47.92 \%$ of the parts of the picture were handled by this skill. It can be seen as a very gratifying result that the comparison skills are included in most of the books in the research group in terms of children gaining their mathematics skills. When the research group is examined in terms of ranking skills, $14.28 \%$ of the text parts of the books are; this skill was found in $9.72 \%$. When the situation of counting in picture story books is examined, it is seen that this skill is included in $\% 95.24 \%$ of the text parts and $92.36 \%$ of the picture parts. In other words, almost all of the books examined have been included in this skill. In this context, it a very gratifying conclusion that the words and images related to the counting skills are almost all of the books examined in the study, but this sensitivity is very important for the development of children's mathematics skills.

Although $6.12 \%$ of the picture story books examined within the scope of the research have basic mathematical concepts and skills, it has been found that they also contain violent words and images that are not suitable for children's development. In the story books, which are one of the children's favorite materials, it is not acceptable in terms of the group to which they are addressed, even if they are included in such elements that will adversely affect their development.

In the light of these results obtained from the research, it can be examined by the commission of related domain experts, phycologists and preschool teachers, and it can be ensured that the publisher behaves more precisely on book publishing. In addition, children's book writers and illustrators can get support from domain experts to include basic mathematical concepts and skills in the content of picture story books and to provide guidance for parents in books. For those who will do research on this subject, it is recommended that they make experimental researches about the acquisition of basic mathematics skills and concepts by using story books. 